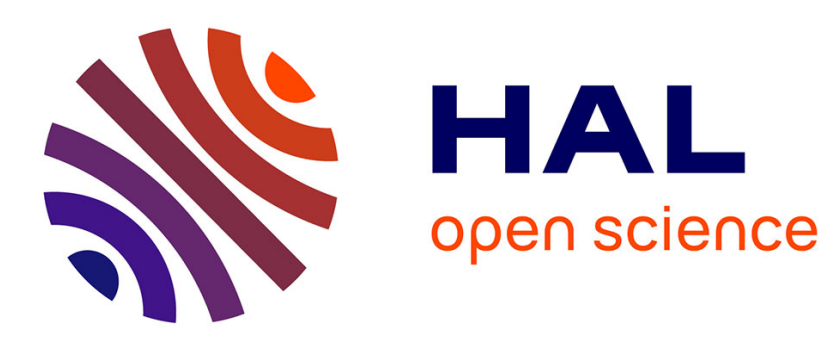

\title{
New data on the ultrastructure of the proboscis in females of Bonellia viridis (Annelida: Bonellinae)
}

Petr Kuznetsov, Alexander Ereskovsky, Elena N Temereva

\section{To cite this version:}

Petr Kuznetsov, Alexander Ereskovsky, Elena N Temereva. New data on the ultrastructure of the proboscis in females of Bonellia viridis (Annelida: Bonellinae). Zoomorphology, 2021, 140, pp.453-468. 10.1007/s00435-021-00541-5 . hal-03383753

\section{HAL Id: hal-03383753 \\ https://hal.science/hal-03383753}

Submitted on 22 Nov 2021

HAL is a multi-disciplinary open access archive for the deposit and dissemination of scientific research documents, whether they are published or not. The documents may come from teaching and research institutions in France or abroad, or from public or private research centers.
L'archive ouverte pluridisciplinaire HAL, est destinée au dépôt et à la diffusion de documents scientifiques de niveau recherche, publiés ou non, émanant des établissements d'enseignement et de recherche français ou étrangers, des laboratoires publics ou privés. 


\section{Zoomorphology}

\section{New data on ultrastructure of proboscis in females of Bonellia viridis (Annelida: Bonellinae) \\ --Manuscript Draft--}

\begin{tabular}{|c|c|c|}
\hline \multicolumn{3}{|l|}{ Manuscript Number: } \\
\hline Full Title: & \multicolumn{2}{|c|}{$\begin{array}{l}\text { New data on ultrastructure of proboscis in females of Bonellia viridis (Annelida: } \\
\text { Bonellinae) }\end{array}$} \\
\hline Article Type: & \multicolumn{2}{|l|}{ Original Article } \\
\hline Keywords: & \multicolumn{2}{|c|}{$\begin{array}{l}\text { echiurids, histology, transmission electron microscopy, epithelium, gland cells, } \\
\text { functional morphology }\end{array}$} \\
\hline Corresponding Author: & \multicolumn{2}{|l|}{$\begin{array}{l}\text { Elena Temereva } \\
\text { Moscow State University, Biological faculty } \\
\text { Moscow, RUSSIAN FEDERATION }\end{array}$} \\
\hline \multicolumn{3}{|l|}{$\begin{array}{l}\text { Corresponding Author Secondary } \\
\text { Information: }\end{array}$} \\
\hline Corresponding Author's Institution: & \multicolumn{2}{|l|}{ Moscow State University, Biological faculty } \\
\hline \multicolumn{3}{|l|}{$\begin{array}{l}\text { Corresponding Author's Secondary } \\
\text { Institution: }\end{array}$} \\
\hline First Author: & \multicolumn{2}{|l|}{ Petr Kuznetsov } \\
\hline \multicolumn{3}{|l|}{ First Author Secondary Information: } \\
\hline \multirow[t]{3}{*}{ Order of Authors: } & \multicolumn{2}{|l|}{ Petr Kuznetsov } \\
\hline & \multicolumn{2}{|l|}{ Alexander Ereskovsky } \\
\hline & \multicolumn{2}{|l|}{ Elena Temereva } \\
\hline \multicolumn{3}{|c|}{ Order of Authors Secondary Information: } \\
\hline \multirow[t]{2}{*}{ Funding Information: } & $\begin{array}{l}\text { российский фонд фуундаментальных } \\
\text { исследований (рфффи) } \\
\text { (20-14-00096) }\end{array}$ & Prof. Elena Temereva \\
\hline & $\begin{array}{l}\text { russian science foundation } \\
(18-04-00082-\mathrm{P})\end{array}$ & Prof. Elena Temereva \\
\hline Abstract: & \multicolumn{2}{|c|}{$\begin{array}{l}\text { Although Bonellia viridis is the best studied echiurid species, many aspects of its } \\
\text { anatomy and ultrastructure are still unclear. In this study, detailed description of } \\
\text { proboscis epithelium of females of B. viridis is done and illustrated by accurate } \\
\text { schemes. Accordingly to histological specificities, four zones of proboscis stem can be } \\
\text { distinguished: dorsal, ventral, and two lateral. These zones differ from each other in } \\
\text { ciliation and abundance of bonellin-producing and gland cells. Each zone supplies } \\
\text { certain functions: protective for dorsal, transport of food particles for ventral, and } \\
\text { agglutination of food particles for lateral. Ciliated cells have been described in } \\
\text { epithelium of the dorsal side of the proboscis stem for the first time. These cells, } \\
\text { probably, supply slow ciliary movements of proboscis. For the first time, the } \\
\text { organization of epithelial cells is described and the ability of epithelial cells to consume } \\
\text { nutrients is detected. The absence of continuous basal lamina under the ventral } \\
\text { epithelium is ascertained. This unusual state may be explained by activity of bonellin- } \\
\text { producing cells, which constantly penetrate between epithelial cells. In bonellin- } \\
\text { producing cells, voluminous perinuclear space and contribution of rough endoplasmic } \\
\text { reticulum into formation of bonellin-containing granules are detected for the first time. } \\
\text { Innervation of epithelial and gland cells occurs via nerve tracts originating from } \\
\text { proboscis nerve cords. In general, echiurid proboscis epithelium exhibits many unusual } \\
\text { features, which are unknown for any other food collecting apparatuses of annelids. The } \\
\text { specificity of organization of proboscis correlates with unique evolutionary } \\
\text { transformation, which echiurids underwent from initially segmented ancestor to recent } \\
\text { non-segmented state. }\end{array}$} \\
\hline
\end{tabular}


1 New data on ultrastructure of proboscis in females of Bonellia viridis (Annelida:

2 Bonellinae)

3 Petr Kuznetsov ${ }^{1}$, Alexander Ereskovsky ${ }^{2-4}$, Elena Temereva ${ }^{1,5, *}$

4

5 Invertebrate Zoology, Leninskie Gory 1, bld. 12, cuznecov.petr2017@yandex.ru

6

7

8

9 ${ }^{2}$ 13007, France, Marseille, Institut Méditerranéen de Biodiversité et d’Ecologie Marine et Continentale (IMBE), Aix Marseille University, CNRS, IRD, Avignon University, Station Marine d'Endoume, Rue de la Batterie des Lions.

${ }^{3} 199034$, Russia, Saint-Petersburg Department of Embryology, Faculty of Biology, SaintPetersburg State University, Universitetskaya nab. 7/9.

4 119334, Russia, Moscow, Koltzov Institute of Developmental Biology of Russian Academy of Sciences, Vavilova street 26. OrcidID: 0000-0003-1079-7204 ${ }^{5}$ 101000, Russia, Moscow, Faculty Biology and Biotechnology, National Research University Higher School of Economics, Myasnitskaya 20, temereva@mail.ru; OrcidID: 00000001-7791-0553

*For correspondence:

Elena N. Temereva

119991, Russia, Moscow, Leninskie Gory 1, bld. 12, Moscow State University, Biological Faculty; temereva@mail.ru

Tel.: +7(495)939-44-95

Fax.: +7(495)939-56-95

${ }^{1}$ 119991, Russia, Moscow, Moscow State University, Biological Faculty, Dept. 


\section{Abstract}

Although Bonellia viridis is the best studied echiurid species, many aspects of its anatomy and ultrastructure are still unclear. In this study, detailed description of proboscis epithelium of females of $B$. viridis is done and illustrated by accurate schemes. Accordingly to histological specificities, four zones of proboscis stem can be distinguished: dorsal, ventral, and two lateral. These zones differ from each other in ciliation and abundance of bonellin-producing and gland cells. Each zone supplies certain functions: protective for dorsal, transport of food particles for ventral, and agglutination of food particles for lateral. Ciliated cells have been described in epithelium of the dorsal side of the proboscis stem for the first time. These cells, probably, supply slow ciliary movements of proboscis. For the first time, the organization of epithelial cells is described and the ability of epithelial cells to consume nutrients is detected. The absence of continuous basal lamina under the ventral epithelium is ascertained. This unusual state may be explained by activity of bonellin-producing cells, which constantly penetrate between epithelial cells. In bonellin-producing cells, voluminous perinuclear space and contribution of rough endoplasmic reticulum into formation of bonellin-containing granules are detected for the first time. Innervation of epithelial and gland cells occurs via nerve tracts originating from proboscis nerve cords. In general, echiurid proboscis epithelium exhibits many unusual features, which are unknown for any other food collecting apparatuses of annelids. The specificity of organization of proboscis correlates with unique evolutionary transformation, which echiurids underwent from initially segmented ancestor to recent non-segmented state.

Key words: echiurids, histology, transmission electron microscopy, epithelium, gland cells, functional morphology 


\section{Introduction}

Accordingly to recent echiurid phylogeny (Goto et al. 2020), bonnelids form separate clade of Bonellinae, which also includes unusual ikedids. Bonellinae is the sister group to all rest echiurids, which form clade Thalassematinae and include two tribes Thalasematini and Echiurini (Goto et al. 2020). Echiurids are marine benthic invertebrates, which body is subdivided into trunk and proboscis (Pilger 1993; Maiorova and Adrianov 2020). The proboscis is usually extended on the surface of substratum and is used to collect and sort of food particles. Certain mechanisms of sorting of food particles are studied very poor (Jaccarini and Schembri 1977a). Moreover, for many echiurids, even position of the proboscis on the substratum is still unclear. For example, some specific structures were discovered in Protobonellia zenkevitchi and allowed to suggest the certain position of proboscis on the substratum (Temereva et al. 2017).

Organization of the proboscis differs in different species. Among echiurids, species from genus Urechis have the shortest proboscis: these echiurids produce the mucous net, which is used for capture of food particles (Fisher and MacGinitie 1928). Most of echiurids have long languagelike proboscis. Females of Bonellia viridis have long proboscis, which terminated by two lobes (Jaccarini and Schembri 1977a). The proboscis of B. viridis is studied in details: there are data on location of proboscis on substratum (Jaccarini and Schembri 1977b), movements of proboscis (Jaccarini and Schembri 1977b), the work of cilia of terminal lobes and middle parts of proboscis (Jaccarini and Schembri 1979), organization of muscles of proboscis (Bosch 1981), the ultrastructure of integument (Bosch and Michel 1979), and blood vessels extended in the proboscis (Amor 1973; Bosch 1984). One of specific features of bonnelids is the presence of bonellin-producing cells, which is located in the connective tissue of body wall and proboscis and are able to penetrate into the integument (Bosch 1979; Bosch and Michel 1979). Bonellin is the pigment, which occurs in many echiuran species, but is well known in B. viridis because makes its body green. This unique pigment this unique pigment has been shown to have various 
toxic and irreversible effects and therefore supplies protective function (Agius and Jaccarini 1981).

Most of ultrastructural data, which we know about echiurids are obtained from $B$. viridis and are extrapolated to other echiurids. At the same time, some of these ultarstructural data seem very unusual (i.e. syncytial nature of wall of the axial blood vessel (Bosch 1984)) and have to be reinvestigated.

Detailed data on organization of the proboscis may help to understand the echiurid biology and some aspects of their feeding behavior (Temereva et al. 2017; Kuznetsov et al. 2021).

The aim of this study is detailed description of ultrastructure of all organ systems of proboscis of B. viridis with special attention to new data concerning organization of integument and functional analysis of these data.

\section{Materials and methods}

Three specimens of Bonellia viridis Rolando, 1822 were collected by SCUBA diving in the Frioul Archipelago on the coast of Provence, France, $43^{\circ} 16^{\prime} 38^{\prime \prime} \mathrm{N}, 5^{\circ} 18^{\prime} 24^{\prime \prime} \mathrm{E}$. The morphology of all individuals was studied with Leica M165C stereomicroscope equipped with a Leica DFC420 digital camera (Leica Microsystems GmbH, Wetzlar, Germany). Proboscises were cut from the trunk and fixed in $2.5 \%$ glutaraldehyde in $0.05 \mathrm{M}$ cacodylate buffer containing $\mathrm{NaCl}$ for 8 hours at +4 C. Materials were then washed in the cacodylate buffer ( 3 times for 4 hours) and were then post-fixed in $1 \%$ osmium tetroxide in the same buffer.

The fine morphology of proboscis was studied by scanning electron microscopy (SEM). Pieces of proboscis and trunk were dehydrated in increasing concentrations of ethanol and acetone; they were then critical point dried, mounted on stubs, and sputter coated with platinum-palladium. 
Specimens were examined with JEOL JSM-6380LA scanning electron microscope (JEOL Ltd., Tokyo, Japan).

For semithin sectioning and transmission electron microscopy (TEM), specimens were dehydrated in increasing concentrations of ethanol and embedded in Embed-812 resin (Electron Microscopy Science, USA). Semi-thin and thin sections were prepared with a Leica UC7 ultramicrotome (Leica Microsystems GmbH, Wetzlar, Germany). Semithin sections were stained with methylene blue, observed with a Zeiss Axioplan2 microscope, and photographed with an AxioCam HRm camera (Carl Zeiss, Oberkochen, Germany). Ultrathin sections were stained with uranyl acetate $(0.5 \%)$ and lead citrate $(0.4 \%)$ and then examined with a JEOL JEM 100B electron microscope (JEOL Ltd., Tokyo, Japan).

\section{Results}

\subsection{Morphology and histology of proboscis}

The body of females of $B$. viridis is subdivided into the trunk and proboscis (Fig. 1A). The proboscis is long projection of the dorsal side of the trunk, which is flattened in dorso-ventral direction and terminates with two large lobes (Fig. 1A, B). The proboscis length can exceed the length of the trunk in several times (Fig. 1A).

The margin of each lobe is swollen and is covered by numerous cilia (Fig. 1C, D). The margin is crossed by vertical grooves, which extend between dorsal and ventral sides of the lobe (Fig. 1C). The diameter of these grooves is about $20-30 \mu \mathrm{m}$. The marginal edge of the lobe bears longitudinal wrinkle, which extends along the margin and divides it on two parts (ventral and dorsal). Accordingly to histological data, this wrinkle is formed by two small epithelial folds, which are associated with huge subepithelial aggregation of gland cells (Fig. 2A). The stem of proboscis is the longest part, which is able to twist and loop. The ventral side of proboscis stem bears shallow longitudinal grooves and is covered by cilia (Fig. 1E). At the proximal end, the 
lateral edges of proboscis are usually directed ventrally and fuse together near the mouth,

121 forming the short ventral collar (Fig. 1F). Near the mouth, proboscis is crossed by transverse groves. In some specimens, the large bulb, which is probably form by the foregut, obstructs the mouth (Fig. 1F).

124 Usually, after fixation, the lateral sides of proboscis bend ventrally (Fig. 2C). Accordingly to 125 specificities of histology, four epithelial zones may be distinguished in the cross section of proboscis: ventral, dorsal, and two laterals. In additional, terminal lobes of proboscis also form specific zone. These zones differ from each other in thickness of epithelium, ciliation, and abundance of gland cells and bonellin-producting cells (Fig. 3A, B). Thus, ventral epithelium has 14-22 $\mu \mathrm{m}$ in thickness, it is heavily ciliated, and contains many bonellin-producting cells and a few epithelial glands (Fig. 4A, B). The epithelium of dorsal side has 10-20 $\mu \mathrm{m}$ in thickness, about lacks cilia, contains a few bonellin-secretory cells and many intraepithelial glands (Fig. 4C). The lateral zones of proboscis look similar to margin of the lateral lobes and are characterized by presence of numerous subepithelial glands (Fig. 4D). Lateral zones of proboscis stem bear ciliated grooves, which diameter is about $20 \mu \mathrm{m}$ (Fig. 2B).

The proboscis lacks spacious inner cavity and is filled with extracellular matrix and muscles (Fig. 2C, D). Muscles are mostly longitudinal and occupy the central and ventral parts of the proboscis, whereas the dorsal side is about lacks muscle cells (Fig. 2C). Fibers of extracellular matrix make a grid, which gather muscles in united construction (Fig. 2D). Rare dorso-ventral muscles are represented by separated muscle fibers. Transverse muscles are not observed on the dorsal side of proboscis, but form a prominent layer under the ventral epithelium (Fig. 2C). The proboscis contains the axial blood vessel extending in its center and two lateral blood vessels, which are incorporated into two lateral coelomic canals (Fig. 2C, D). Two lateral nerve cords extend along lateral sides of the proboscis above the coelomic canals (Fig. 2C, D). The nerve cord gives rise to the neurite bundles, which penetrate the connective tissue and extend to the subepithelial (Fig. 2A) and intraepithelial gland cells (Fig. 4A). 
147 The epithelium consists of epithelial, intraepithelial and subepiermal gland cells of different types (Fig. 3C). All types of cells are organized similarly in all four zones of the proboscis.

149 Epithelial cells of ventral side bear numerous cilia, which form dense cover above the 150 epithelium (Figs. 4B, 5A). Apical surface of epithelial cells bears branched microvilli and large apical protrusions, which are covered by flocculent material of cuticle (Fig. 5A, B). The kinetosome is represented by one centriole (basal body), which connects with two striated rootlets: transverse and longitudinal (Fig. 5C). Cells connect each other via adherence and septate junctions, which unite the apical parts of cells (Fig. 5C, D). The middle and basal parts of cells contact each other loosely; therefore voluminous intracellular spaces are visible (Fig. 5B, C). The cytoplasm of apical part of cells is electron dense and is armed by transverse bundles of actin filaments (Fig. 5B). The apical cytoplasm is filled with numerous vesicles of different diameter and multivesicular bodies (Fig. 5B, C). The middle and basal parts of cell contain large nucleus of irregular shape, several Golgi apparatuses, and phagosomes (Fig. 5A-C). Epithelium is not underlined by continuous basal lamina (Fig. 5A).

In epithelial cells of lateral sides of proboscis, because of presence of many cilia, the apical protrusions and microvilli are not such numerous as in the epithelium of ventral side (Fig. 6A). The epithelium of lateral sides is underlined by thin basal lamina. Epithelial cells of dorsal side are about lack cilia, nevertheless some ciliated cells can be detected (Fig. 6B). In cells, which lack cilia, the apical part is substantially protruded and forms wide lobes (Fig. 6C). Because of presence of apical protrusions, cell junctions are located in subapical zone. Apical membrane forms thick microvilli, which exposed into the layer of cuticle, and numerous thin canals, which penetrate the cytoplasm of apical protrusions. These canals terminate by pinocytotic vesicles, which fill the apical cytoplasm (Fig. 6C). In cells of dorsal epithelium, bundles of actin fibers extend are not only transverse, but are also longitudinal. 
Intraepithelial gland cells are incorporated into the epithelia of all four zones and do not form

172 protrusions into extracellular matrix (Figs. 3, 7A, B). There are two types of intraepithelial gland cells: with electron-lucent vacuoles and with electron-dense flocculent granules. Cells of first type (with electron-lucent vacuoles) are the most abundant especially in dorsal epithelium (Figs. 4C, 7A). These cells are filled with vacuoles of different diameter, which contain electron-lucent material and many vesicles of smaller diameter. Apical surface of cells bears thin short microvilli with electron-dense cytoplasm. Usually, apical surface of gland cells is covered by apical projections of epithelial cells (Fig. 7A, B). Gland cells of first type connect with the epithelial cells via adherence and septate junctions (Fig. 7A). Secretory zone of cell is located in middle part of cell and is represented by Golgi apparatus, which is squeezed between vacuoles (Fig. 7A). Epithelial gland cells of second type contain granules of electron-dense flocculent material, which diameter is about $0.6-0.8 \mu \mathrm{m}$ (Fig. 7B). Cells of this type are rare and are usually occurred in dorsal epithelium.

Subepithelial gland cells are numerous in terminal lobes and in lateral zones of the proboscis stem. There are two types of subepithelial gland cells (Figs. 3, 8A, B). Cells of first type contain large roundish electron-dense granules, which diameter can reach up $1.5 \mu \mathrm{m}$ (Fig. 8A). The nucleus is relatively large, is irregular-shaped, and contains nucleolus (Fig. 8A). The secretory zone contains numerous Golgi apparatuses, which canals are filled with content of middle electron density (Fig. 8B). Vacuoles, which are produced by Golgi apparatuses, fuse together forming granules of middle electron density (Fig. 8A); then the density of granules becomes higher. Subepithelial gland cells of second type are filled with huge vacuole, which contains electron-lucent material and flocculent fibers (Fig. 8B). The nucleus is located in the central part of cell: it is relatively small in diameter and contains much heterochromatin and nucleolus. The secretory zone is also located in the central part of cell and is represented by numerous Golgi apparatuses, which canals are filled with electron-lucent content (Fig. 8B). 
Bonellin-producing cells are specific type of subepithelial gland cells. These cells contain 197 electron-dense granules of specific ovoid shape and maximal size 2x1 $\mu \mathrm{m}$ (Fig. 9A). Bonellinproducing cells can also contain granules of irregular shape and middle electron density. These cells are mostly located in the connective tissues of the proboscis, but can be also incorporated into the epithelium (Figs. 3, 4, 9A). These cells have lengthy apical and swollen basal parts. Apical membrane forms thick short microvilli. Apical part of bonellin-producing cells does not form typical cells junctions with adjacent cells (Fig. 9A). Apical cytoplasm is filled with electron-dense granules. The secretory zone is located in the basal part of cell and contains two main elements: Golgi apparatuses and rough endoplasmic reticulum (RER) (Fig. 9C). Canals of Golgi apparatuses are filled with electron dense content (Fig. 9C). The RER connects the nuclear membrane: the perinuclear space is very wide and sophisticatedly lopped, thus, canals of RER penetrate the perinuclear space (Fig. 9C). The RER produce flocculent electron-dense material, which is incorporated in the secretory granules. Moreover, secretory granules are located into space, which is surrounded by RER canals (Fig. 9B). Some areas of cell membrane are very thick and electron dense (Fig. 9C). Cells are closely contacted the nerve tracts and some certain neurites (Fig. 9C).

Intraepithelial and subepithelial gland cells and bonellin-producing cells are well innervated by nerve tracts, which originate from the lateral nerve cords (Figs. 4A, 5A, 9B). Bundles of neurites also penetrate between epithelial cells (Fig. 6A). Usually, nerve tracts consist of neurites of two types. Neurites of first type have large diameter, electron-lucent cytoplasm, and contain dense-core synaptic vesicles (Figs. 3C, 5A). Neurites of second type are small in diameter, have electron-dense cytoplasm, and contain synaptic vesicles with electron-lucent content. Neurites connect each other via synapses (Fig. 9B).

\section{Discussion}


Most echiurans are deposit-feeders, and the proboscis is used to collect food particles from the

221

222

223

224 substrate (e.g., Ikeda 1904; Baltzer 1931; Hughes and Crisp 1976; Biseswar 1991; Hughes et al. 1993; Jumars 2015; Kharlamenko et al. 2018). Accordingly to available data, mucus ciliary mechanism woks for capture of food particles: they adhere to the mucus, which is produced by gland cells, and then transport to the mouth due to activity of cilia (Biseswar 1991). Accordingly to many observations, the dorsal side of the proboscis usually faces the substratum and ventral side usually faces the water; the distal edge is submerged into the substratum and collects substrate particles (Biseswar 1991; Hughes et al. 1993; Goto et al. 2016). The specific position of the proboscis has been suggested for Protobonellia zenkevitchi due to specificities of morphology and histology of different zones of proboscis (Temereva et al. 2017). B. viridis uses the terminal lobes but not the lateral sides of the proboscis to collect food particles (Jaccarini and Schembri 1977a). Accordingly to our new data, the margin of terminal lobes of proboscis bears the huge aggregation of gland cells. The same cells are located along the lateral sides of the proboscis stem. The presence of similar gland cells in both terminal lobes and lateral sides of the proboscis stem may evidence the similar function of these zones, i.e. production of mucus for adherence of food particles. It probably means that the lateral edges of proboscis stem are involved into collection of food particles.

The size of food particles, which echiurids are able to capture, can vary greatly: $2-7 \mu \mathrm{m}$ in Lissomiema mellita (Kuznetsov et al. 2021), 7-45 $\mu \mathrm{m}$ in P. zenkevitchi (Temereva et al. 2017), 90-300 in B. viridis (Jaccarini and Schembri 1977a). Usually, the size of food particles is determinated by diameter of ciliary grooves, which extend on certain zones of proboscis (Temereva et al. 2017; Kuznetsov et al. 2021). In B. viridis, ciliary grooves are detected on the margin of the terminal lobes and on the lateral sides of the proboscis stem. In both parts of the proboscis, the diameter of ciliated grooves is similar and is about $20 \mu \mathrm{m}$. The presence of ciliated grooves may evidence the sorting of food particles in B. viridis. The rejection of particles occurs on the ventral side of the proboscis and near the mouth (Jaccarini and Schembri 1977b; Pilger 
1993). In studied specimens of $B$. viridis, the detected protrusion of the foregut may work as an

247 obstacle for large particles.

248 Distribution of muscles, cells, and fibers in extracellular matrix of proboscis has functional meaning. Thus, in P. zenkevitchi, the terminal part of the proboscis is reinforced by large vacuolated cells (Temereva et al. 2017). In L. mellita, proboscis is very muscular and its ventral side is reinforced by thick layer of collagenous fibers (Kuznetsov et al. 2021). In B. viridis, muscles are mostly extended in central and ventral parts; moreover, the ventral epithelium is underlined by layer of transverse muscles. These muscles allow the proboscis to curve on the ventral side and form a kind of large groove (Fig. 2C).

Ultrastructure of epithelium of proboscis is described for B. viridis in several papers (Pilger, 1977; Jaccarini and Schembri 1977a; Bosch and Michel 1979; Bosch 1979). These studies are mostly devoted to the description of gland cells, whereas epithelial cells have never been described in details. It is known that cells of ventral epithelium bear cilia, whereas cells of dorsal epithelium lack cilia (the exception is the dorsal side of terminal lobes of B. viridis) (Jaccarini and Schembri 1977a). Accordingly to our data, some cells of dorsal epithelium have cilia, that allow it to move slowly due to ciliary beating. In general, epithelial cells of all zones of proboscis are organized in similar way. It is very interesting that all epithelial cells are able to consume nutrients: the Figure $7 \mathrm{~B}$ allows to realize the formation of pinocytotic vesicles, their aggregation into multivesicular bodies, and further transformation into the phagosomes. Because of pinocytotic activity epithelial cells contain large and well developed Golgi apparatuses, which produce lysosomes. The consumption activity of epithelial cells is consistent with suggestion that some intraepithelial glands produce proteins, which may be used for digestion of food prior to entering the mouth (Bosch and Michel 1979).

The subapical location of cells junction in dorsal epithelium allows it to stretch when the proboscis skirts on the ventral side. Another one interesting and unusual thing is the absence of 
continuous basal lamina under the ventral epithelium. Strictly speaking, epithelium, which is not

272 underlined by basal lamina, cannot be regarded as true epithelium (Vracko 1974). The absence

273 of basal lamina in ventral epithelium may be caused by activity of bonellin-producing cells,

274 which constantly penetrate between epithelial cells and change the structure of epithelium (see

275 below).

276 Accordingly to literature, five types of gland cells can be distinguished in proboscis of females of B. viridis: two intraepithelial and three subepithelial (Bosch and Michel 1979). Intraepithelial gland cells had been detected in ventral epithelium only (Bosch and Michel 1979). As it was shown in our study, two types of intraepiermal gland cells are scattered in ventral and dorsal epithelia; moreover, dorsal epithelium contains many mucus-producing cells. The secretion of these cells is apparently used for protection of dorsal epithelium, which contacts the substratum.

Three types of subepithelial gland cells are associated with ventral (one type) and dorsal (two types) epithelia (Bosch and Michel 1979). Ventral mucus gland cells contain hypertrophied Golgi apparatus and produce large vacuoles, which then fuse together, forming the united mass with fibrillary network. The secretion of these cells contains sulfated mucus and is used for agglutination of food particles (Bosch and Michel 1979). Dorsal mucus cells contain ovoid granules, which consist of sulfated mucopolysaccharides and are used for protection of dorsal epithelium. The third type of subepithelial cells is represented by dorsal twisted mucus gland cells, which contain well developed RER, two Golgi apparatuses, and numerous metachromatic granules. The secretion of these glands may help to provide traction for the animal as it crawls over the surface (Bosch and Michel 1979). Accordingly to our data, there are two types of subepithelial gland cells and both types are associated with the terminal lobes and with the lateral sides of the proboscis stem. The secretion of these gland cells may be used for agglutination of food particles. 
Ultrastructure of bonellin-producing cells has never been described in details (Pilger 1993). It is known that Golgi apparatus produces the material of bonellin-containing granules and then the granules are modified in cytoplasm (Kawaguti 1968). Our new data show that the bonellincontaining granules are produced by two ways (by Golgi apparatuses and by RER) and probably consist of at least two components. Unusual thing of bonellin-producing cells is the presence of wide perinuclear space, which is penetrated by canal of RER and contains the bonellin granules. The dense parts of cell membrane may play role for movements of bonellin-producing cells, which are able to move in connective tissue and form projections penetrating between epithelial cells (Bosch 1979). The abundance of bonellin-producing cells in the ventral epithelium is consistent with light sensitivity of bonellin: it releases due to mechanical or light stimuli. Because ventral epithelium is faced to the light, it contains much more bonellin-producing cells in comparison with dorsal epithelium, which is faced to the substratum.

For the first time, the innervation of epithelium, gland cells, and bonellin-producing cells has been shown in our study. In previous researches, the innervation of gland calls and bonellinproducing cells has not been detected (Pilger 1993).

\section{Conclusion}

For the first time for echiurans, detailed description of epithelium of proboscis is done and visualized as accurate schemes. Four functional zones are distinguished in proboscis stem: dorsal, ventral, and two lateral. These zones differ from each other in ciliation and abundance of bonellin-producing and gland cells. Accordingly to specificities of histology, each zone provides certain function. Thus, dorsal side works for protection of proboscis, ventral - for transport of food particles, and lateral for agglutination of food particles. Many unusual and previously undescribed features are discovered: the capability of epithelial cells to consume nutrients via pinocytosis, the absence of continuous basal lamina under the ventral epithelium, the presence of ciliary cells in dorsal epithelium of the proboscis stem, the innervation of epithelial cells and 
320 gland cells by nerve tracts, and the specificities of bonellin-producing cells. In sum, epithelium

321 of proboscis exhibits many unusual features, which are unknown for any food collecting

322

323

324

325

326

327 apparatuses of annelids. The specificity of organization of proboscis correlates with unique evolutionary transformation, which echiurids underwent from initially segmented ancestor to recent non-segmented state.

\section{Acknowledgements}

This study was conducted with financial support from the Russian Science Foundation (\#18-0400082-P), Russian Foundation for Basic Research (\#20-04-00096), and supported by the Vernadski Grant of the French Embassy in the Russian Federation. The research was performed at the User Facilities Center of M.V. Lomonosov Moscow State University with financial support from the Ministry of Education and Science of the Russian Federation. The study was also supported by a Moscow State University Grant for Leading Scientific Schools "Depository of the Living Systems" within the MSU Development Program. The work of AE was conducted under the IDB RAS Government basic research program in 2021 № 0088-2021-0009. We thank the Morphology Service of the Mediterranean Institute of Marine and Terrestrial Biodiversity and Ecology (IMBE) for technical support. We are grateful to Laurent Vanbostal, OSU Pytheas, Marseille for Bonnelia viridis collection.

\section{Conflict of Interest Statement}

The authors declare that they do not have any conflict of interest. All authors have read the text and approved the final version of the manuscript.

\section{Author contributions}


PK performed the histology, prepared the serial sections, made some schemes, and photographed the sections. AE collected and fixed the animals, helped interpret the results, and helped write the manuscript. ET prepared all figures, wrote the manuscript, and interpreted the results.

\section{References}

Agius L, Jaccarini V (1981) Effects of light in pigment development in the echuran worm Bonellia viridis. J. Zool 193:33-37.

Amor A (1973) Modelos de sistema vascular en Echiura. Asoc Argentina Ciencias Nat Physis Buenos Aires 32:115-120.

Baltzer F (1931) Echiurida, in: Kückenthal W, Krumbach T (Eds.) Handbuch Der Zoologie. DeGruyter, Berlin, pp 62-168.

Biseswar R (1991) Burrowing, Locomotion and Other Movements of the Echiuran Ochetostoma caudex. Acta Zool 72:91-99. https://doi.org/10.1111/j.1463-6395.1991.tb00321.x

Bosch C (1979). Les cavidades de la trompa de Bonellia viridis (Rolando, 1821): revision anatomica y ultraestructural. Publicaciones del Dep Zool Univ Barcelona 4:23-30.

Bosch C (1981) La musculature, le squelette conjonctif et les mouvements de la trompe de la Bonellie (Bonellia viridis, Echiuridae). Ann Sci Nat Zool 3:203-229.

Bosch C (1984) Les vaisseaux sanguins de la trompe chez Bonellia viridis (Echmrien) et leur musculature a fonction multiple. Ann Sci Nat Zool 6:3-32.

Bosch C, Michel C (1979) Ultrastructural and histochemical study of the glands of the proboscis in Bonellia viridis Echiura. Cell Mol Biol 25:233-246.

Fisher WK, MacGinitie GE (1928) A new echiuroid worm from California Ann Mag Nat Hist (Series 10) 1:199-204.

Goto R, Monnington J, Sciberras M, Hirabayashi I, Rouse GW (2020) Phylogeny of Echiura updated, with a revised taxonomy to reflect their placement in Annelida as sister group to Capitellidae. Invertebr Syst 34:101-111. https://doi.org/10.1071/IS19020

Goto R, Sakamoto S, Hayakawa J, Seike K (2016) Underwater observations of the giant spoon worm Ikeda taenioides (Annelida: Echiura: Ikedidae) in a subtidal soft-bottom environment in northeastern Japan, which survived tsunamis of the 2011 off the Pacific Coast of Tohoku Earthquake. J Oceanogr 73:103-113. https://doi.org/10.1007/s10872-016-0380-2

Hughes DJ, Ansell AD, Atkinson RJA, Nickell LA, Ansell AD, Atkinson RJA, Nickell LA (1993) Underwater television observations of surface activity of the echiuran worm Maxmuelleria lankesteri (Echiura: Bonelliidae). J Nat Hist 27:219-248. https://doi.org/10.1080/00222939300770081

Hughes DJ, Crisp DJ (1976) A further description of the echiuran Prashadus pirotansis. J Zool 180:233-242.

Ikeda I (1904) The gephyrea of Japan. J Coll Sci Imp Univ Tokyo, Japan pp 1-87

Jaccarini V, Schembri PJ (1979) The proboscis ciliation of the echiuran Bonellia viridis. J Mar Biol Assoc United Kingdom 59:377-384.

Jaccarini V, Schembri PJ (1977a) Feeding and particle selection in the echiuran worm Bonellia 
Jaccarini V, Schembri PJ (1977b) Locomotory and other movements of the proboscis of Bonellia viridis (Echiura, Bonellidae). J Zool Lond 182:467-476.

Jumars PA, Dorgan KM, Lindsay SM (2015) Diet of worms emended : an update of polychaete feeding guilds. Annu Rev Mar Sci 7:497-520. https://doi.org/10.1146/annurev-marine010814-020007

Kawaguti S (1968) Electron microscopy on blue-green algae in the body-wall of an echiurold Jkedosoma gogoshimense. Biol Jpn Okayairna Univ 14:67-74

Kharlamenko VI, Maiorova AS, Ermolenko EV (2018) Fatty acid composition as an indicator of the trophic position of abyssal megabenthic deposit feeders in the Kuril Basin of the Sea of Okhotsk. Deep Res Part II Top Stud Oceanogr 154. https://doi.org/10.1016/j.dsr2.2018.03.005

Kuznetsov PA, Maiorova AS, Temereva EN (2021) New data on echiuran anatomy and histology: the case of Lissomyema mellita (annelida: Thalassematidae). Zool 144. https://doi.org/10.1016/j.zool.2020.125865

Maiorova AS, Adrianov AV (2020) Biodiversity of echiurans (Echiura) of the Kuril-Kamchatka Trench area. Prog Oceanogr 180. https://doi.org/10.1016/j.pocean.2019.102216

Pilger JF (1977) Biology and Gametogenesis of Listriolobus pelodes (Echiura). Dissertation, University of Southern California

Pilger JF (1993) Echiura, in: Microscopic analomy of invertebrates, Volume 12: Onychophora, Chilopoda, and Lessser Protostomata. Willey-Liss Inc, pp 186-236.

Temereva EN, Kuznetsov PA, Kiseleva EA (2017) The morphology and microscopic anatomy of the deep-sea echiurid Protobonellia zenkevitchi Murina, 1976. Russ J Mar Biol 43:447-464. https://doi.org/10.1134/S1063074017060104

Vracko R (1974) Basal lamina scaffold. Anatomy and significance for maintenance oforderly tissue structure. Am J Path 77:314-346. 


\section{Figure legends}

411

412

413

414

415

Fig. 1. Morphology of females of Bonellia viridis. a-b Photographs of fixed animals; c-f SEM. a Whole animal viewed from the left. b Terminal lobes of proboscis. c A part of one terminal lobe; longitudinal wrinkle of margin is pointe by arrowheads. $\mathbf{d}$ A portion of margin of terminal lobe, which is heavily ciliated. e A portion of ventral side of the proboscis stem. $\mathbf{f}$ Anterior part of the body viewed from the top; large bulb of foregut obstructs the mouth. $c i$ cilia, $c g$ ciliated groove, $c h$ chaetae, $d s$ dorsal side of terminal lobe, $f b$ foregut bulb, $l g$ longitudinal groove, $m$ mouth, $m e$ marginal edge of terminal lobes, $p s$ proboscis stem, $t g$ transverse groove, $t l$ terminal lobe, $t r$ trunk, $v c$ ventral collar.

Fig. 2. Anatomy proboscis of female of Bonellia viridis. a-c Photographs of transverse semithin sections; d SEM. a A portion of margin of terminal lobe: huge aggregation of subepidermal glands is visible. b Ciliated groove of lateral side of the proboscis stem. c Whole proboscis stem. d A portion of proboscis stem: grid, which is formed collagenous fibers, is evident. $a b v$ axial blood vessel, $a g c$ aggregation of gland cells, $b p c$ bonellin-producing cells, $c f$ collagenous fibers, $c g$ ciliated groove, $d e p$ dorsal epithelium, $d v m$ dorso-ventral muscles, $l b c$ lateral blood vessel, $l c$ lateral coelomic canal, $l m$ longitudinal muscles, $l n c$ lateral nerve cord, $l s$ lateral side, $n b$ neurite bundle, $t m$ transverse muscles, vep ventral epithelium.

Fig. 3. Schemes of histological and ultrastructural organization of proboscis of female of Bonellia viridis. a Portion of terminal lobe. b Portion of the proboscis stem. c Ultrastructure of ventral epithelium of proboscis stem. $b p c$ bonellin-producing cells, $c i$ cilia, $c u$ cuticle, igc-I intraepidermal gland cell type I, igc-II intraepidermal gland cell type II, $m c$ muscle cells, $m i$ microvilli, $n$ nucleus, $n b$ neurite bundle, pha phagosome, pns perinuclear space, sgc-I subepidermal gland cell type I, sgc-II subepidermal gland cell type II.

Fig. 4. Histological organization of proboscis of female of Bonellia viridis; photographs of transverse semithin sections. a Ventral epithelium of terminal lobe. b Ventral epithelium of 
proboscis stem. c Dorsal epithelium of proboscis stem. d Lateral epithelium of proboscis stem. $b p c$ bonellin-producing cells, $c i$ cilia, $c t$ connective tissue, igc-I intraepidermal gland cell type I, igc-II intraepidermal gland cell type II, $m c$ muscle cells, $n b$ neurite bundle, $s g c-I$ subepidermal gland cell type I, $s g c-I I$ subepidermal gland cell type II.

Fig. 5. Ultrastructure of ventral epithelium of proboscis stem in female of Bonellia viridis; TEM.

a General view of epithelium and neurite bundles under the epithelium. b Apical parts of epithelial cells; space between to adjacent cells is marked by asterisks. c Organization of kinetosome and rootlets of cilia; wide spaces between cells are marked by asterisks. d Septate junction between adjacent cells. af actin filaments, aj adherence junction, ap apical projection, $b p c$ bonellin-producing cells, ce centriole, $c i$ cilia, $c t$ connective tissue, $c u$ cuticle, igc-I intraepidermal gland cell type I, $I r$ lateral rootlet, $m i$ microvilli, $m v b$ multivesicular body, $n$ nucleus, $n b$ neurite bundle, pha phagosome, $p v$ pinocytotic vesicle, sj septate junction, tr transverse rootlet.

Fig. 6. Ultrastructure of lateral and dorsal epithelia of proboscis stem in female of Bonellia viridis; TEM. a General view of epithelium of lateral side. b Apical part of ciliated cell of dorsal epithelium. c Apical and middle parts of epithelial cell of dorsal epithelium. af actin filaments, $a j$ adherence junction, ap apical projection, $b l$ basal lamina, $b p c$ bonellin-producing cells, $c e$ centriole, $c i$ cilia, $c u$ cuticle, $G$ Golgi apparatus, igc-II intraepidermal gland cell type II, $l r$ lateral rootlet, $m c$ muscle cell, $m i$ microvilli, $m v b$ multivesicular body, $n$ nucleus, $n b$ neurite bundle, $p h a$ phagosome, $s j$ septate junction, tr transverse rootlet.

Fig. 7. Organization of intraepidermal gland cells in dorsal epithelia of proboscis stem in female of Bonellia viridis; TEM. a Gland cell of first type contains large vesicles with electron-lucent content. b Gland cells of second type contains granules of electron dense flocculent material. $a j$ adherence junction, ap apical projection, $c u$ cuticle, $G$ Golgi apparatus, igc-I intraepidermal 
459 gland cell type I, igc-II intraepidermal gland cell type II, mi microvilli, $m v b$ multivesicular body, $460 \quad n$ nucleus, pha phagosome, $v$ vesicle.

461 Fig. 8. Organization of subepidermal gland cells in lateral zones of proboscis stem in female of 462 Bonellia viridis; TEM. a Gland cell of first type contains large electron dense granules. b Gland 463 cell of second type contains mucous material and many Golgi apparatuses. ecm extracellular 464 matrix, $G$ Golgi apparatus, $g r$ granule of secretion, $m s$ mucus secretion, $n$ nucleus, $n u$ nucleolus, $465 n g r$ newly formed granule, $s g c-I$ subepidermal gland cell type I, $s g c-I I$ subepidermal gland cell 466 type II, sve secretory vesicles.

467 Fig. 9. Organization of bonellin-producing cells of proboscis stem in female of Bonellia viridis; 468 TEM. Electron dense portions of cell membrane are pointed by arrowheads. a Cell incorporated 469 into ventral epithelium. b Cell in connective tissue. G Golgi apparatus, $g r$ granule of secretion, 470 mi microvilli, $n$ nucleus, $n b$ neurite bundle, $n g r$ newly formed granule, pha phagosome, pns 471 perinuclear space, RER rough endoplasmic reticulum, sy synapse. 


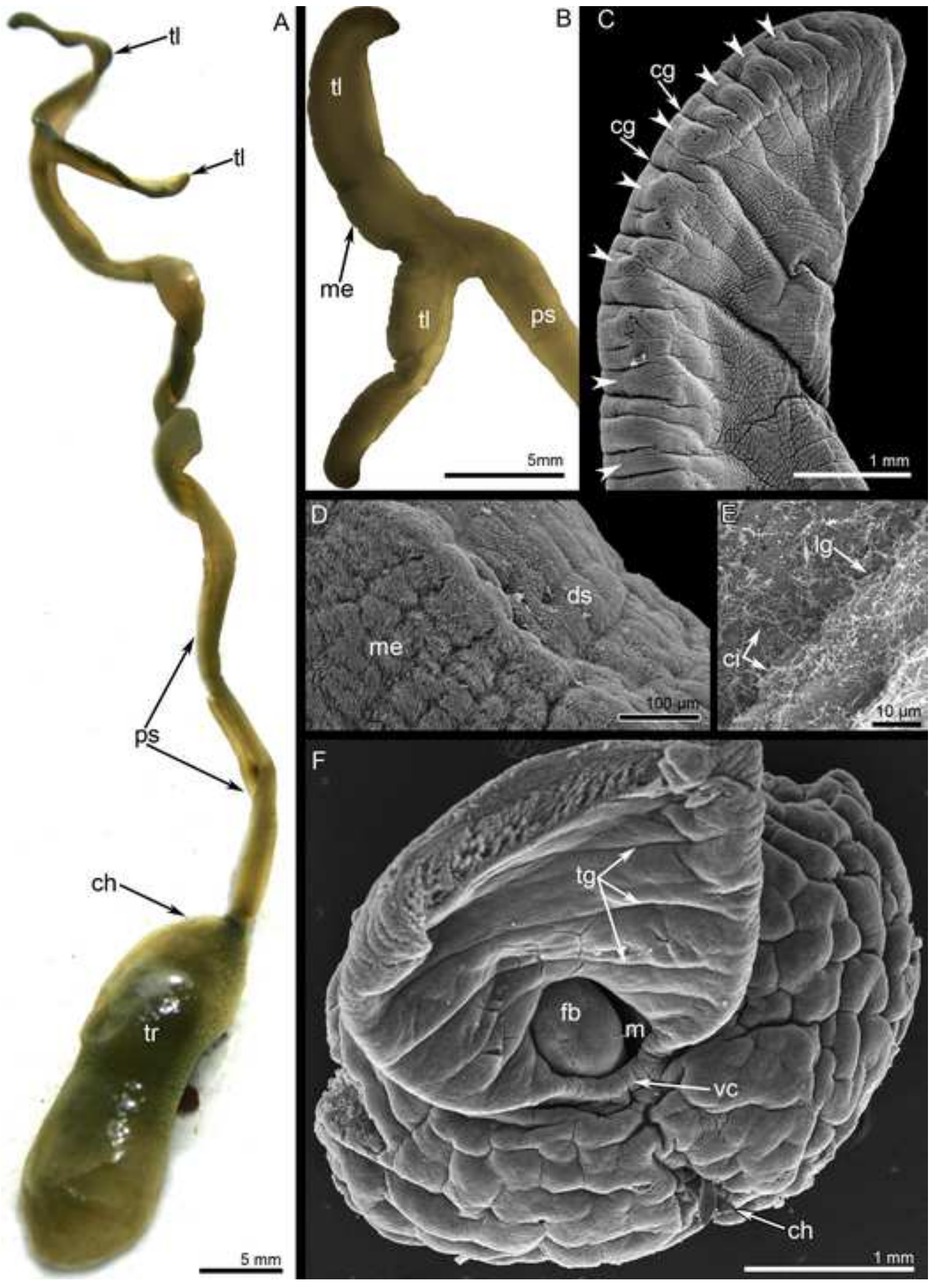



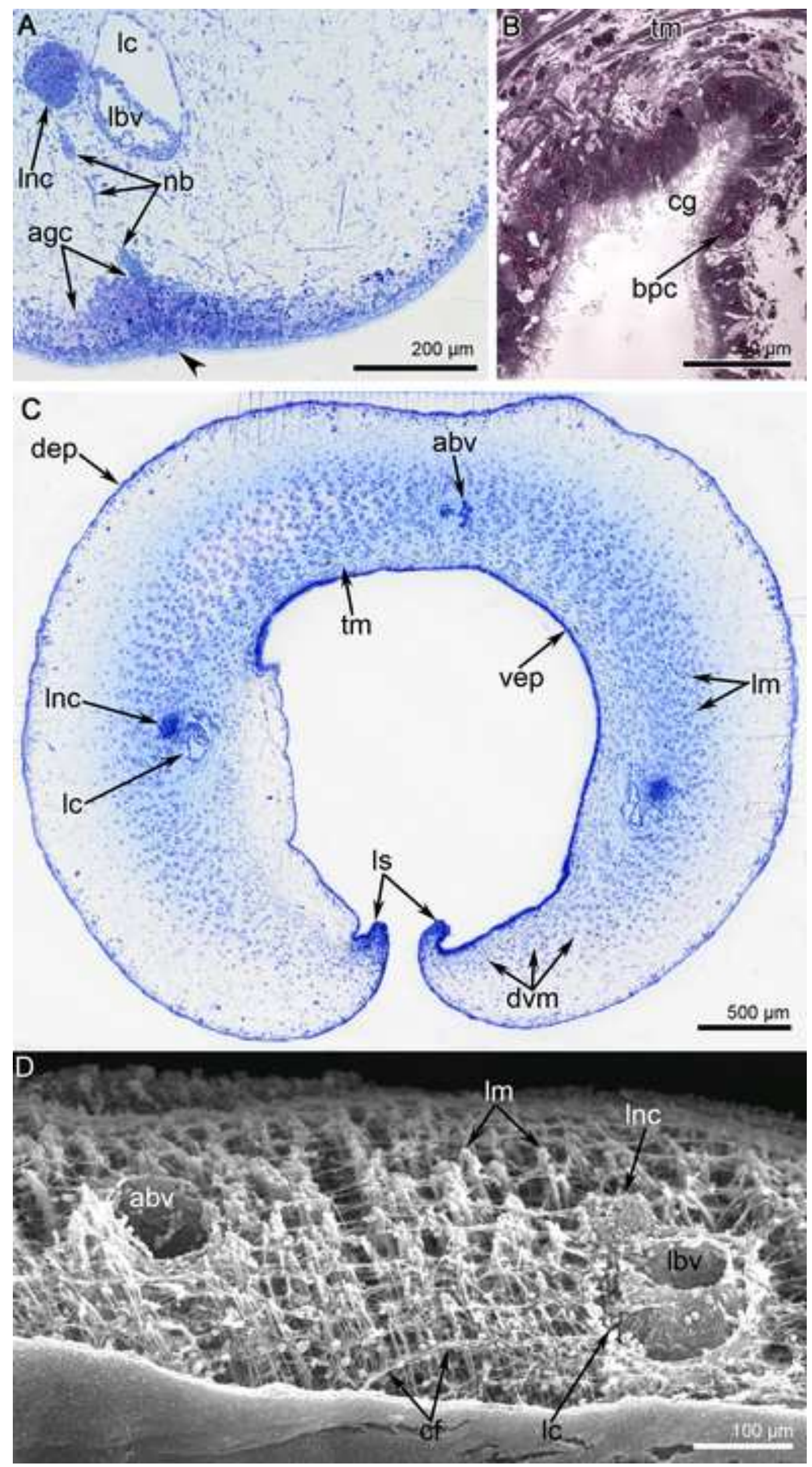

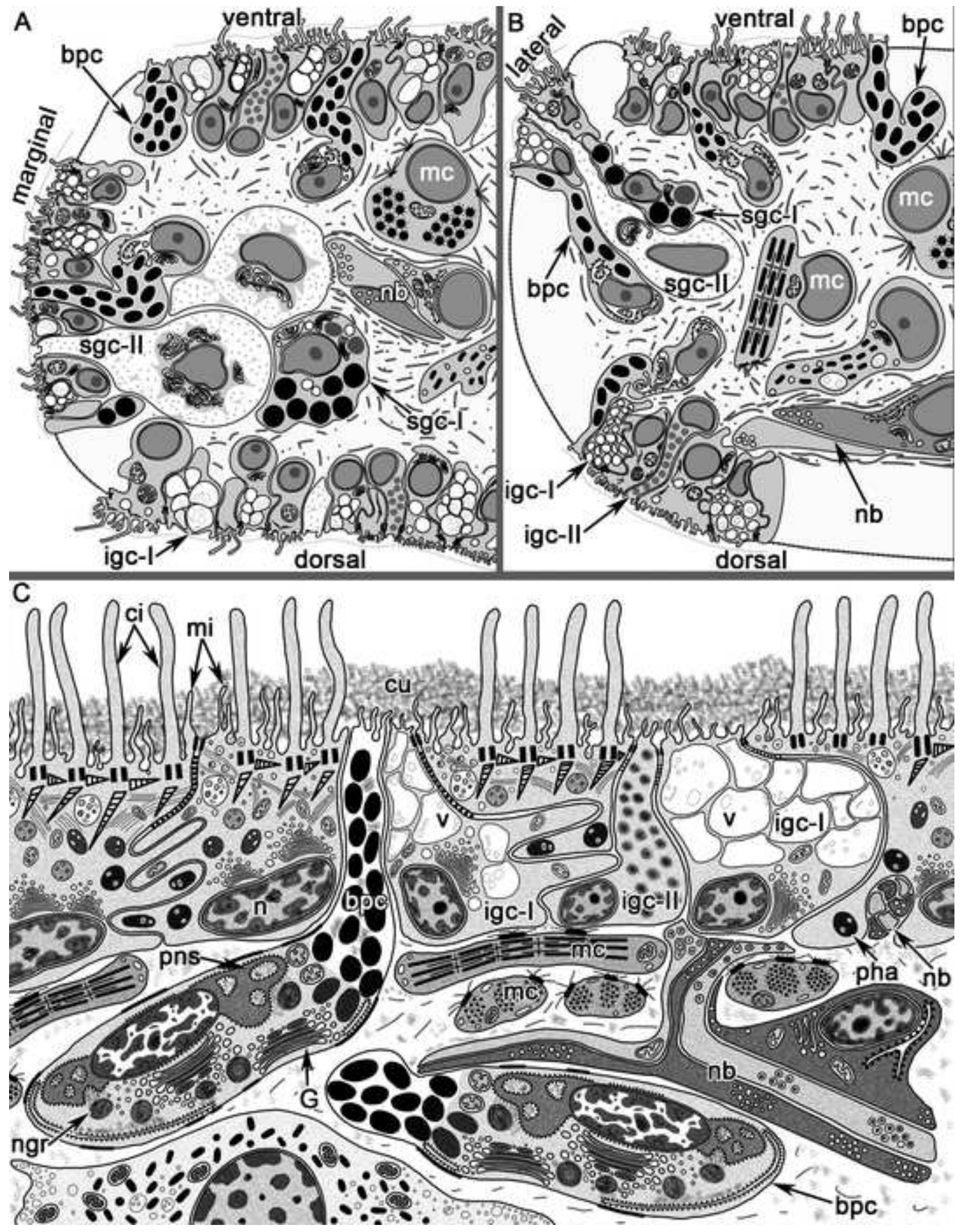

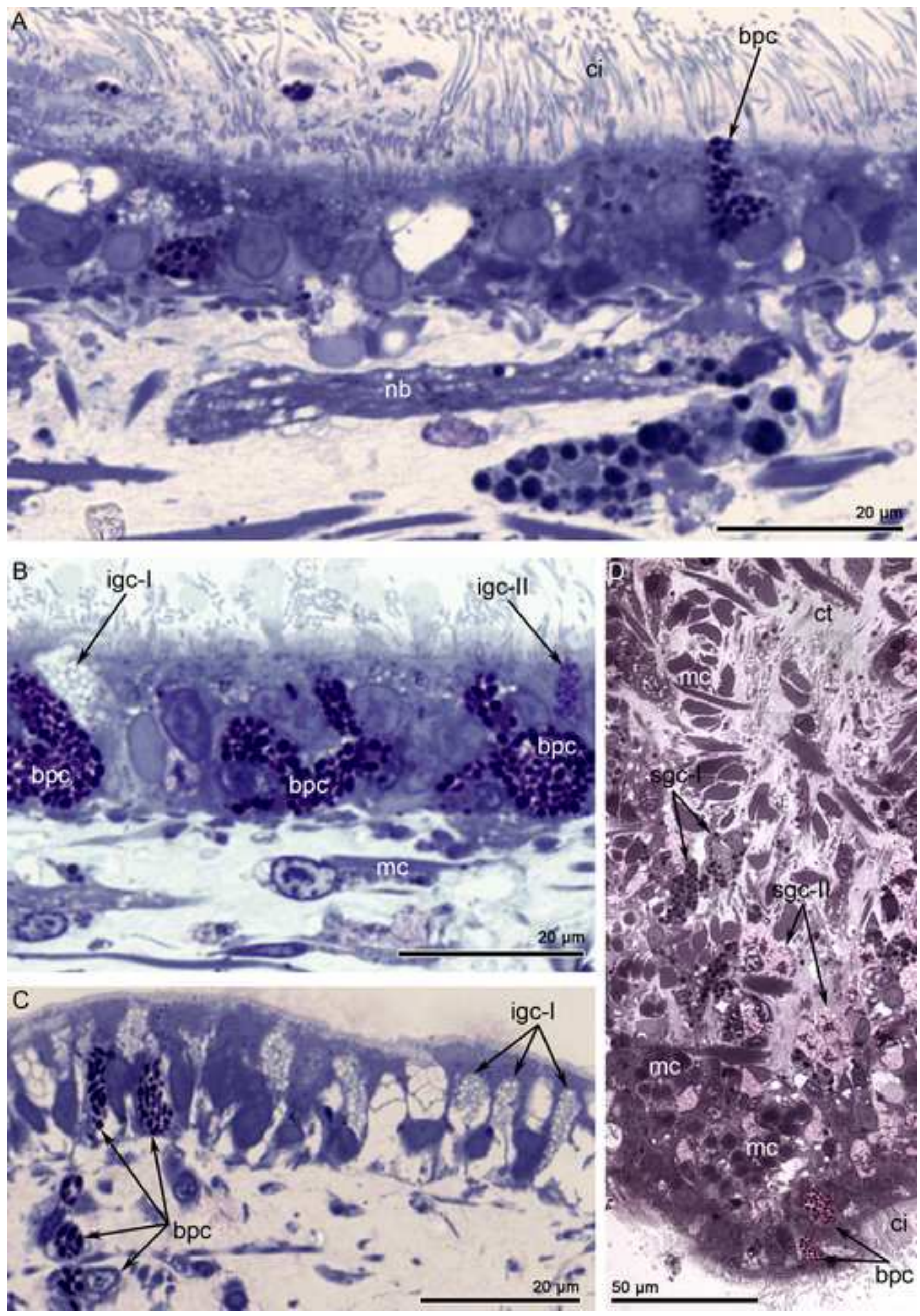

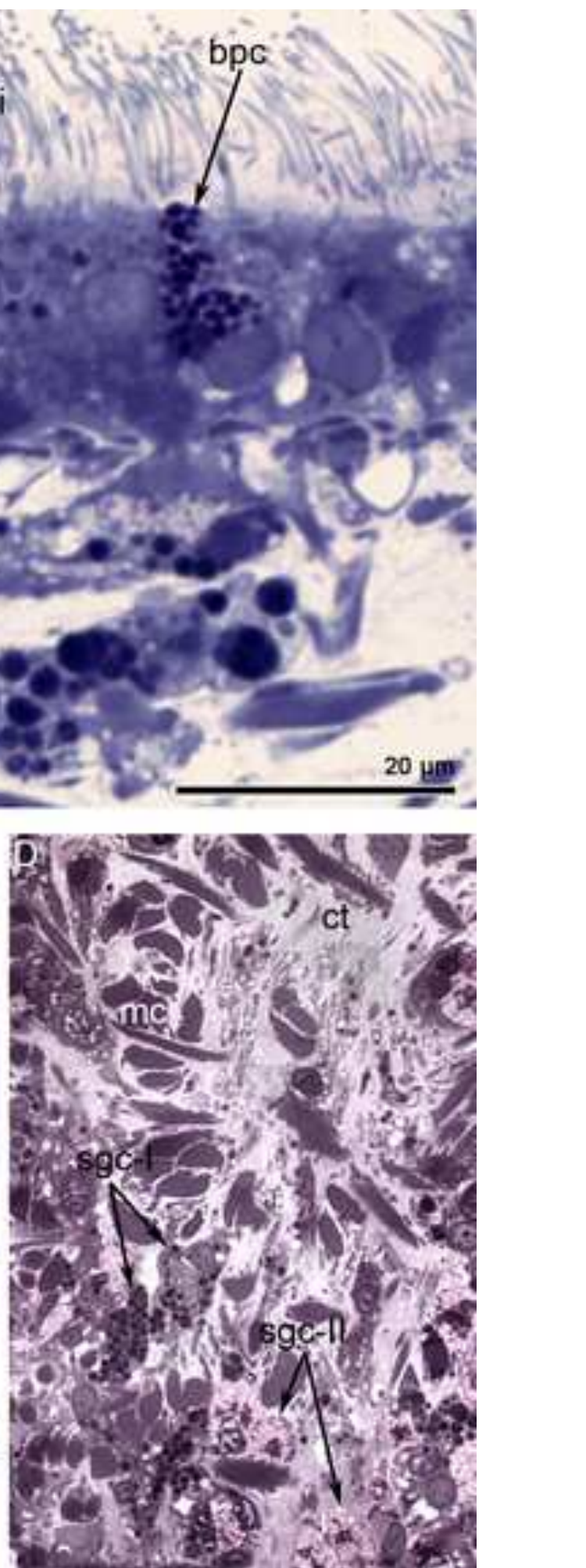

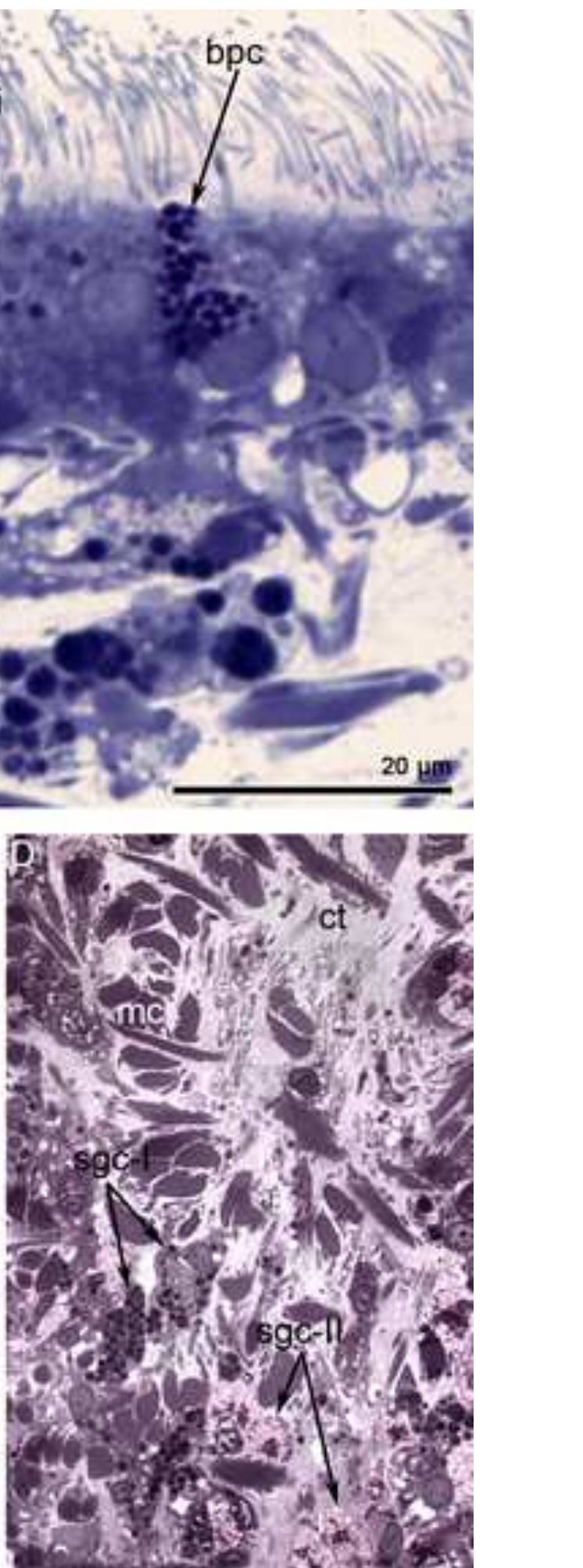

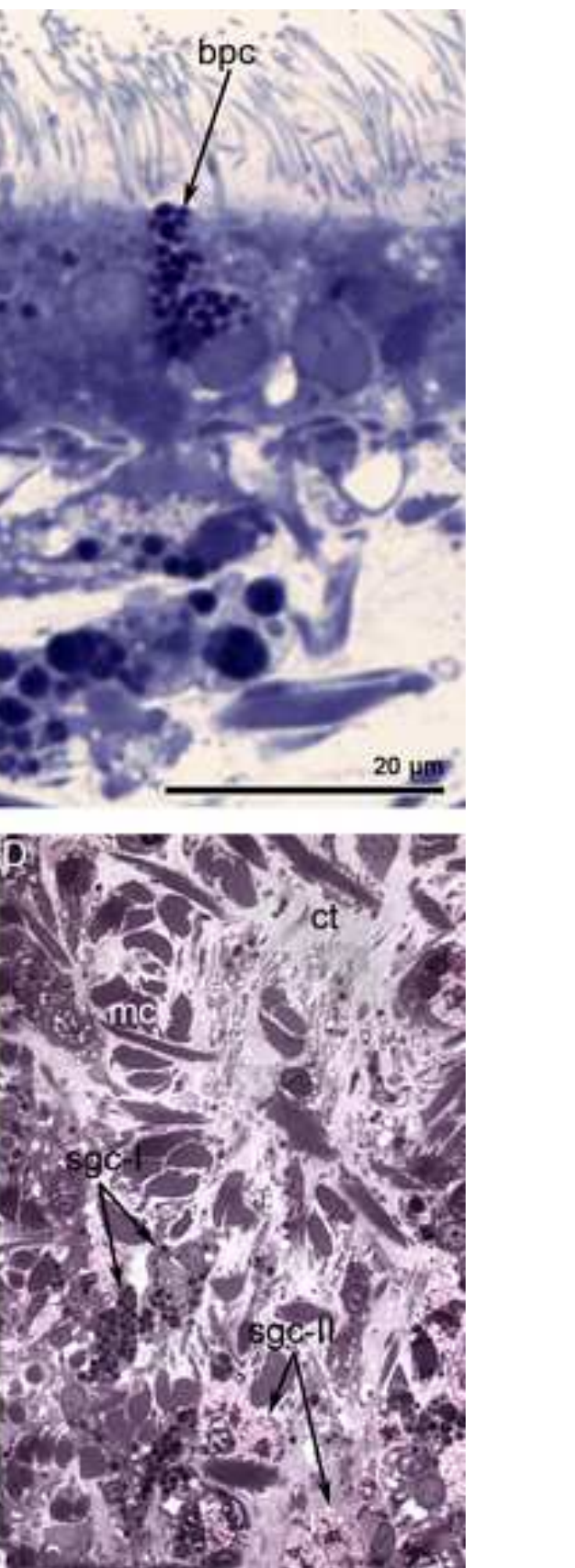

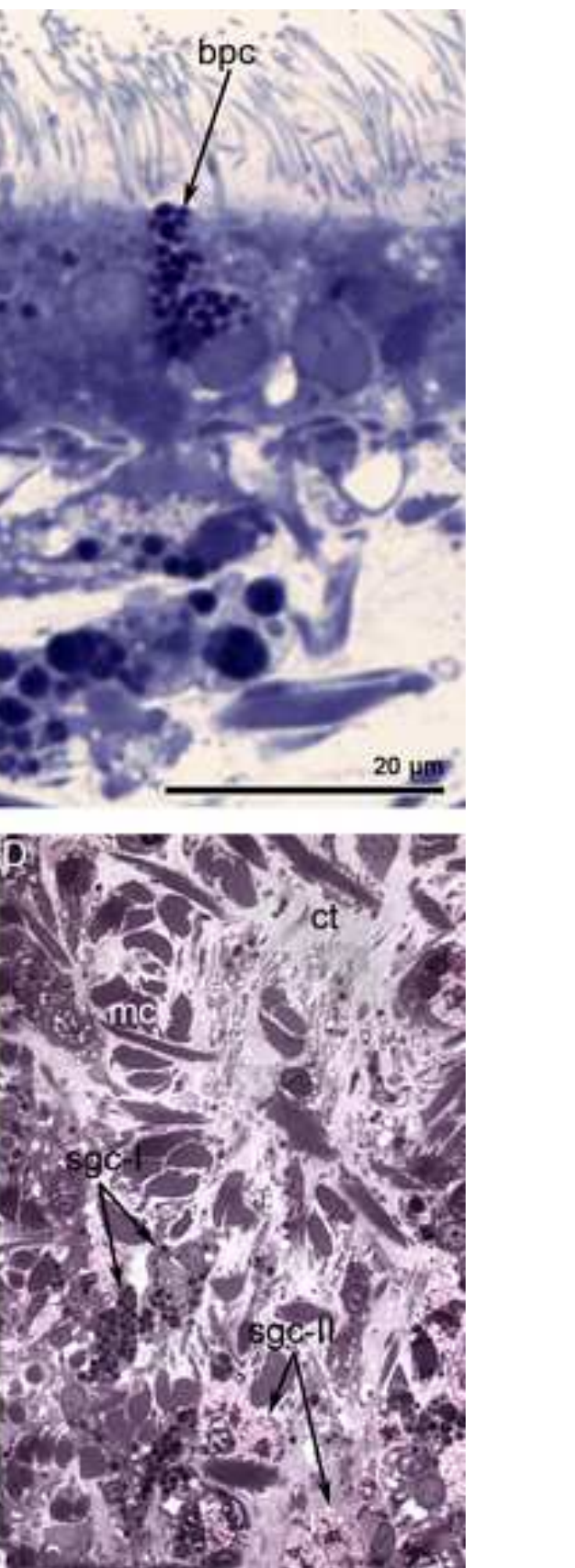

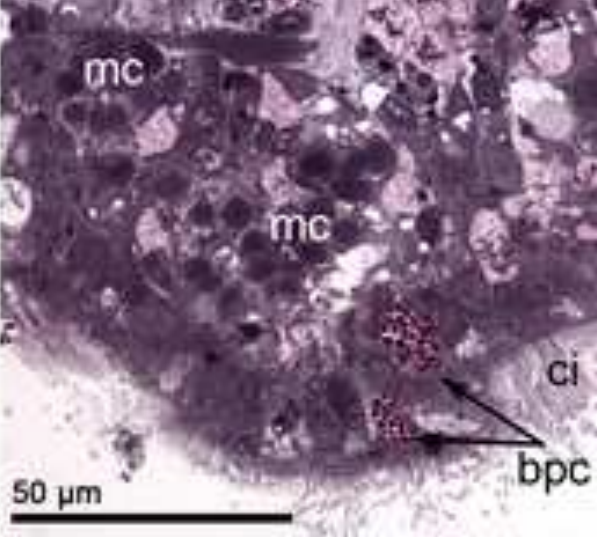




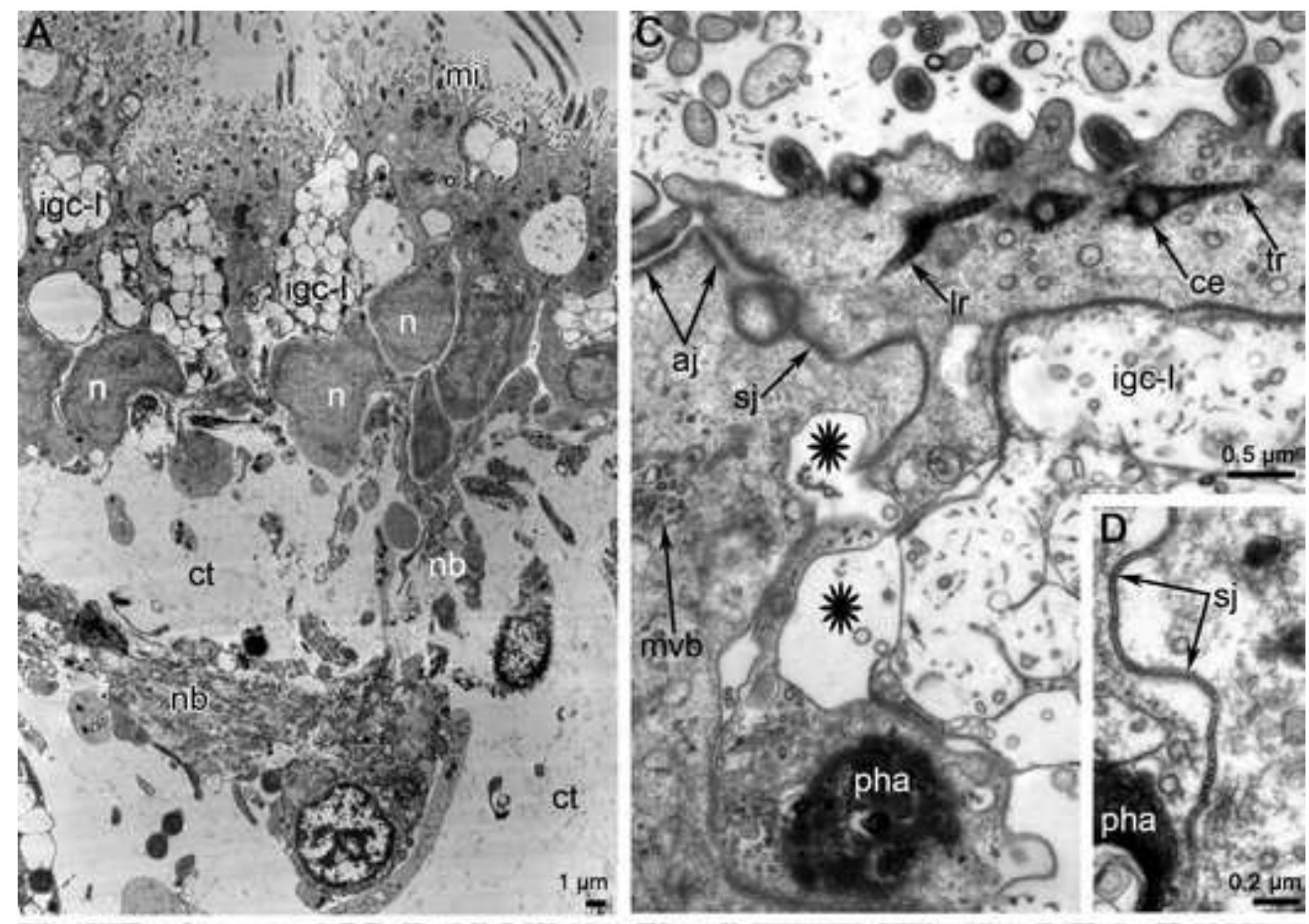

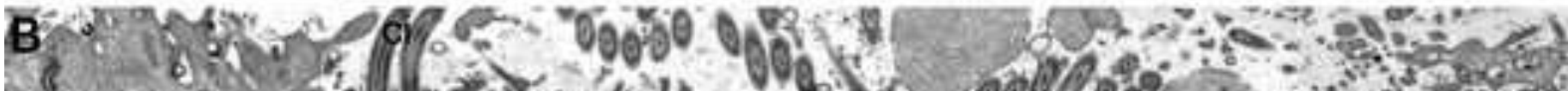

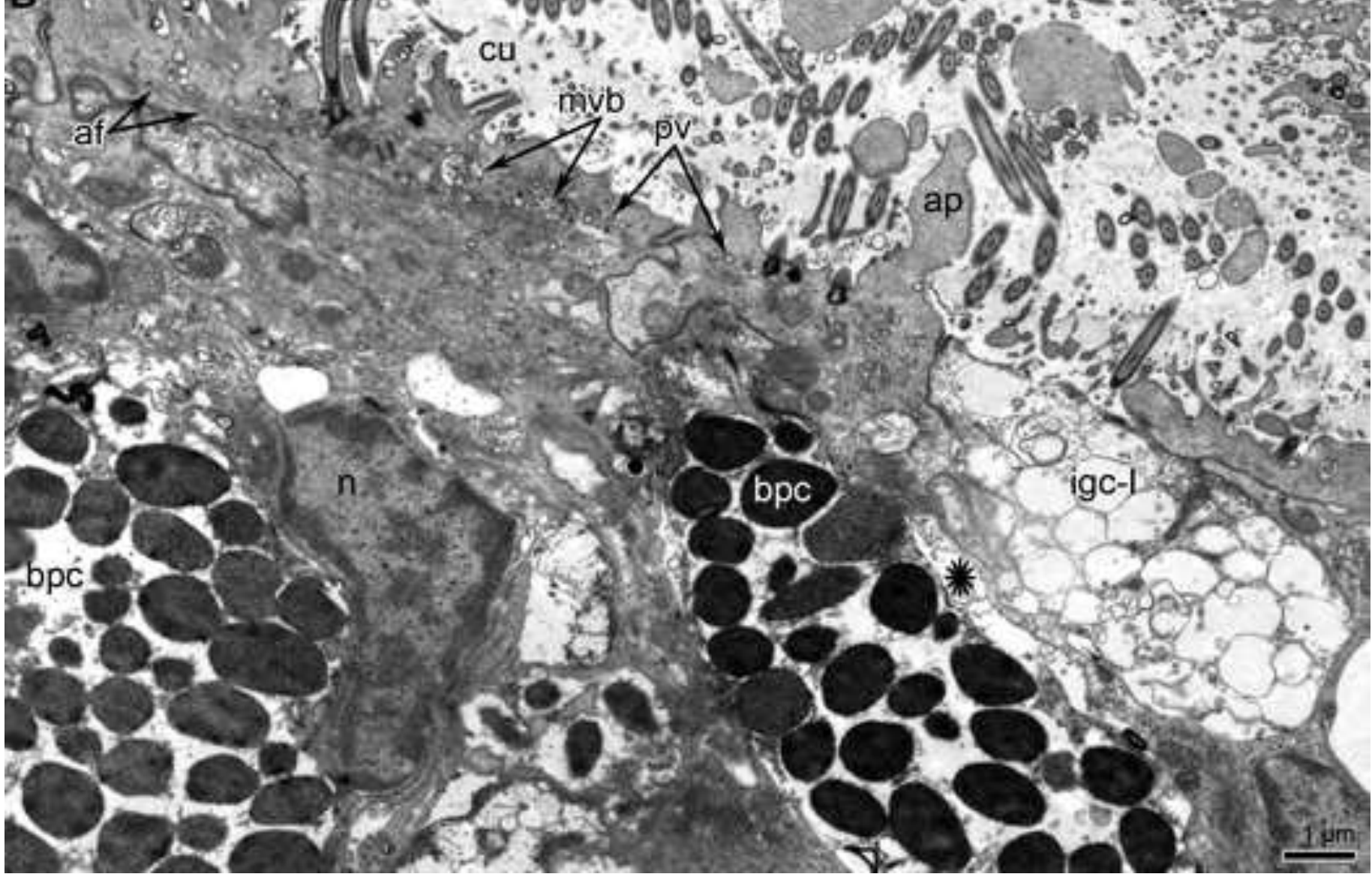




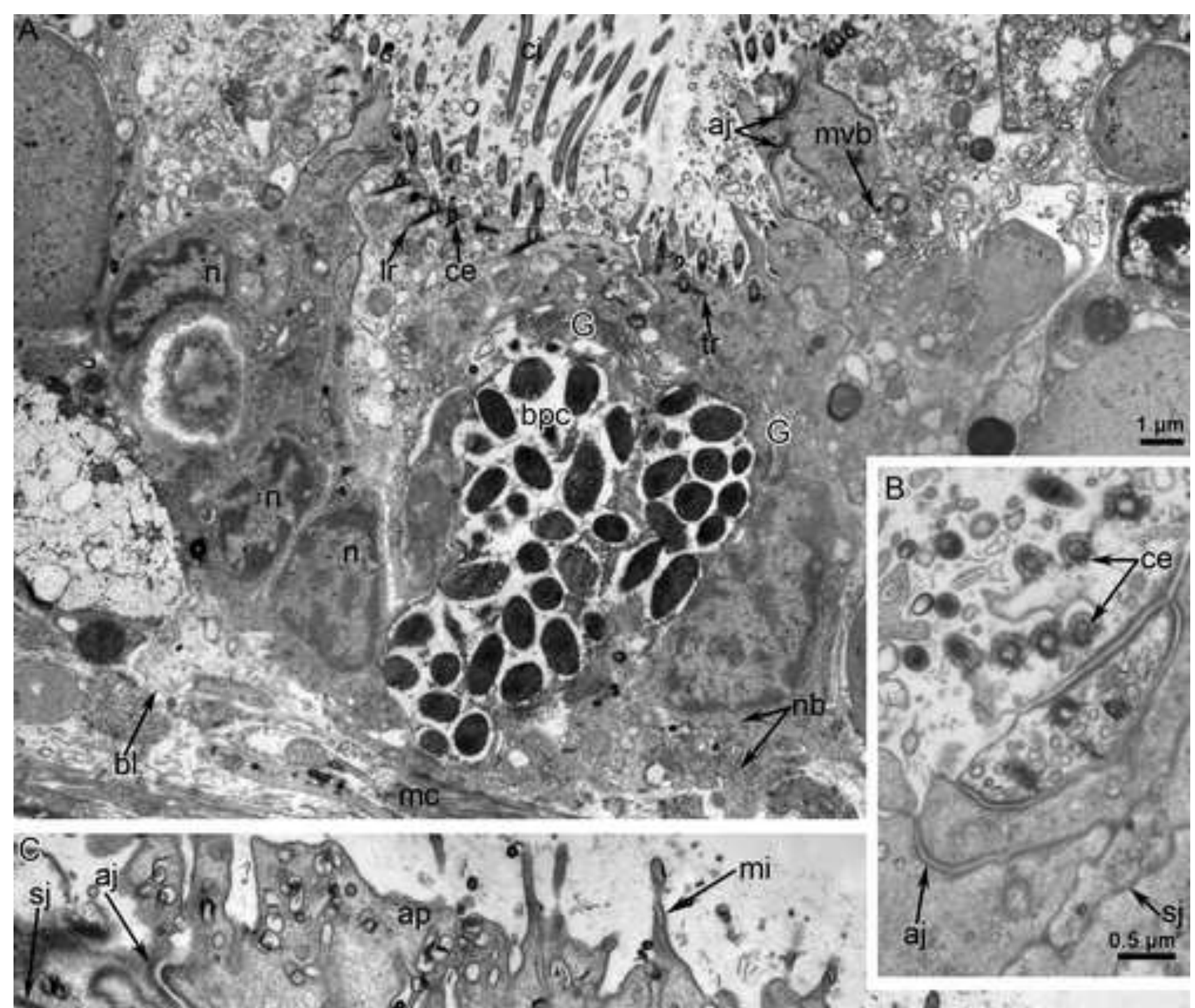

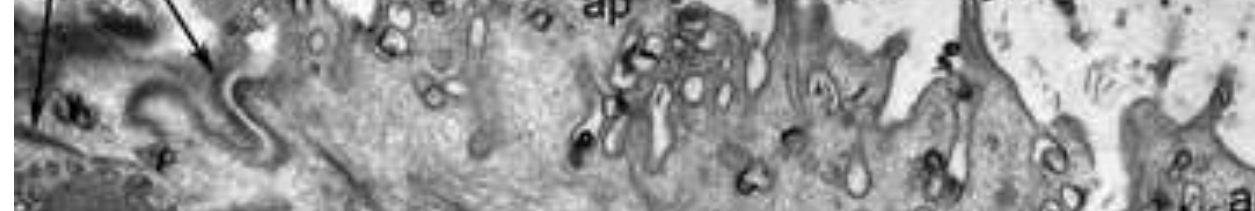

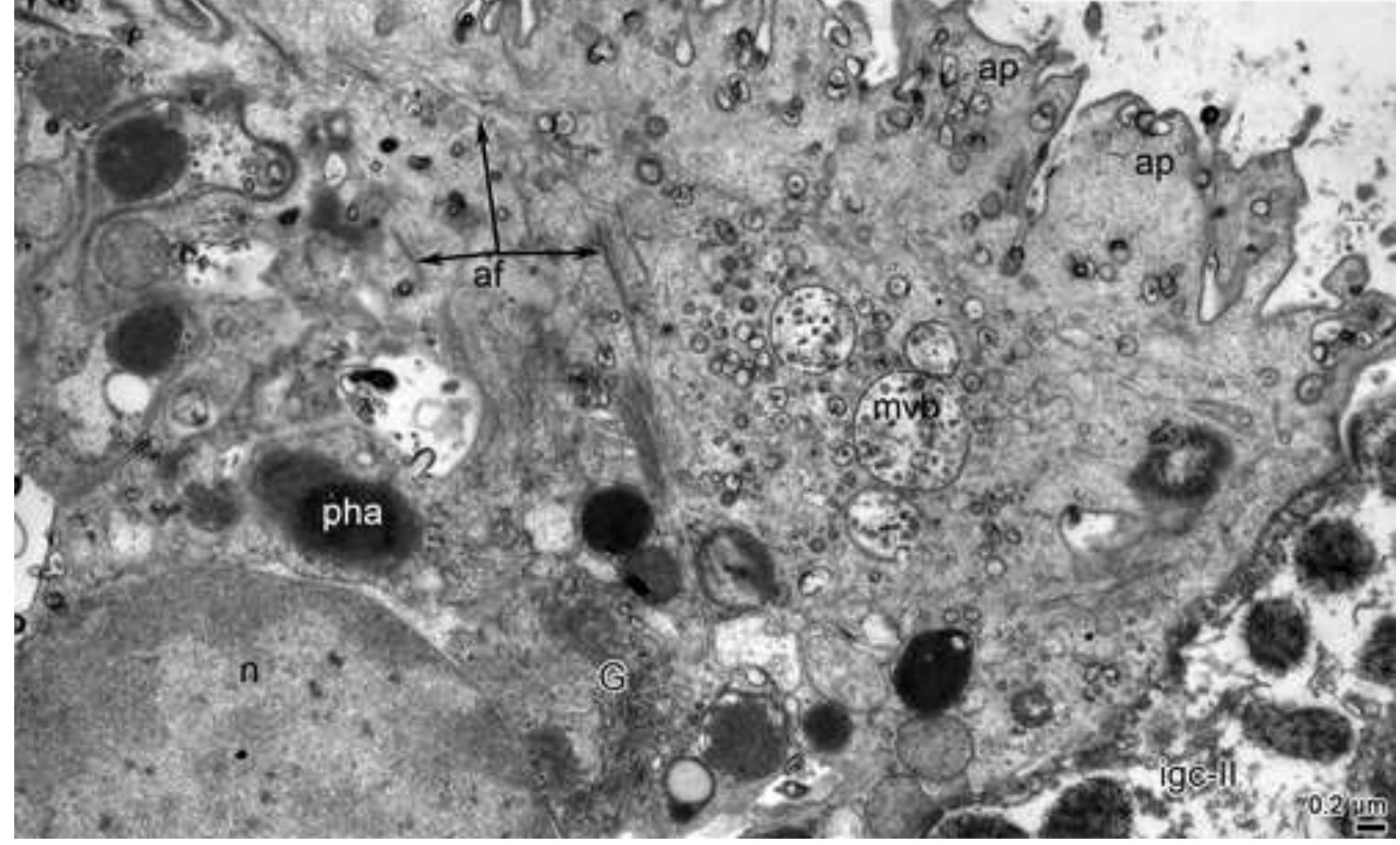



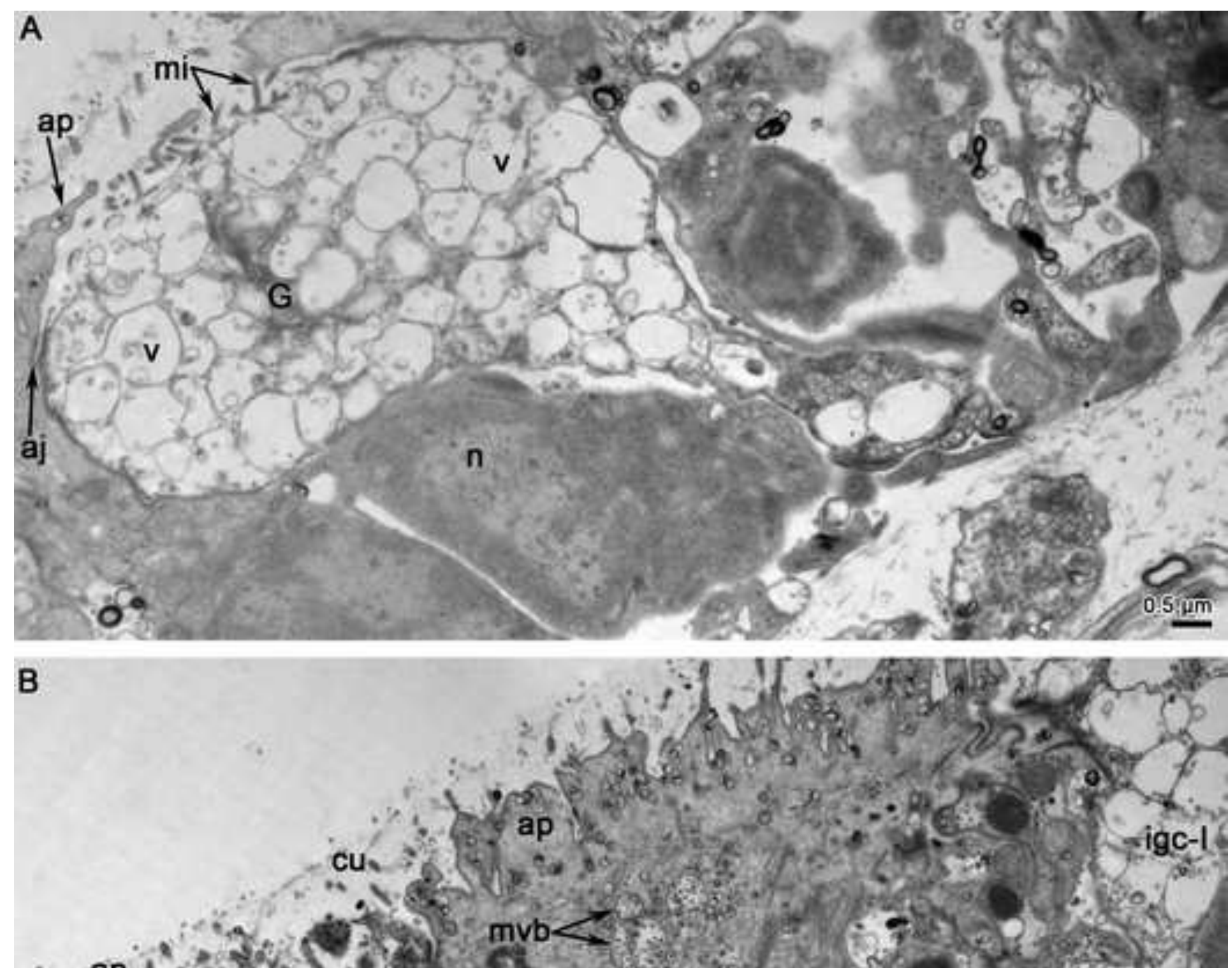

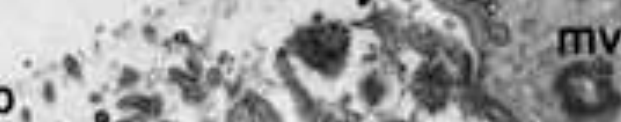

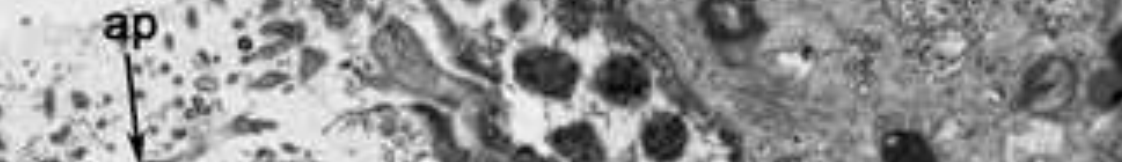

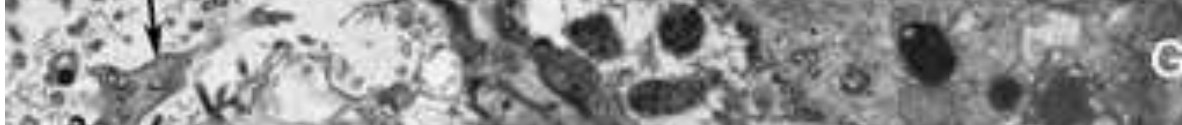

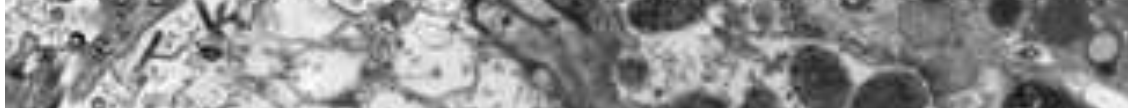

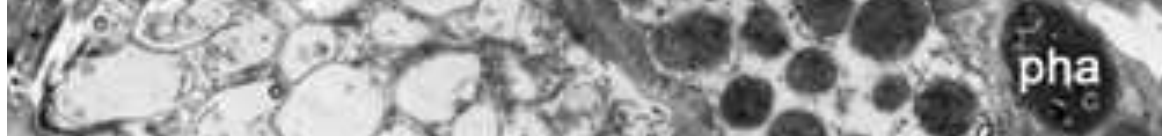

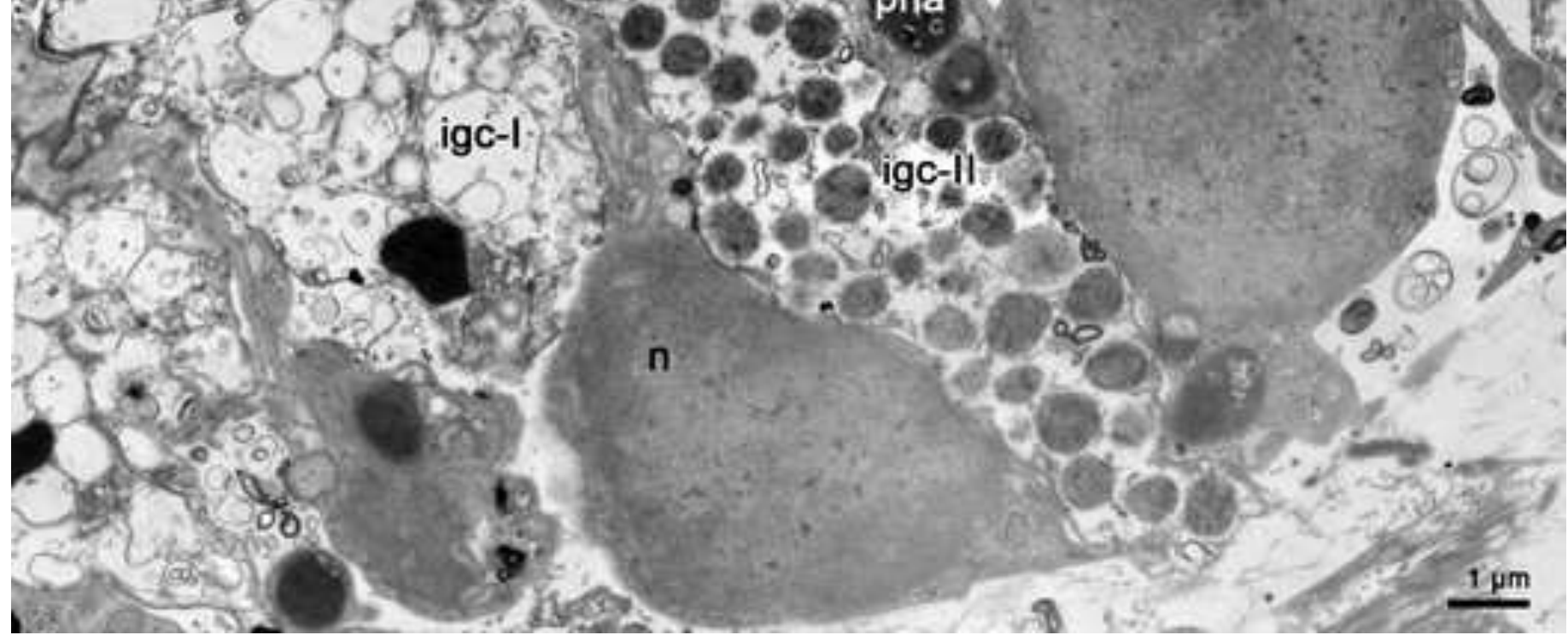




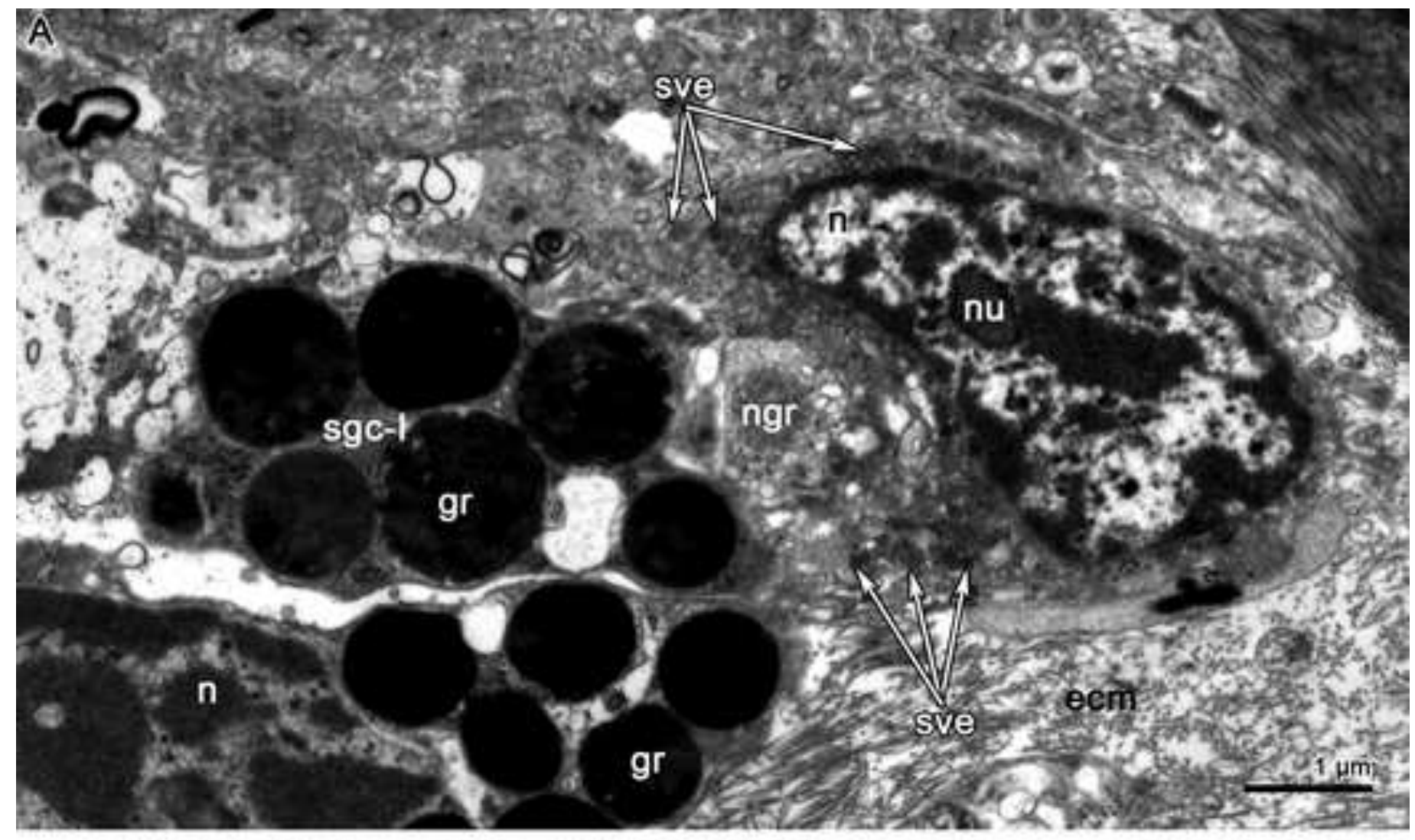

171090 on

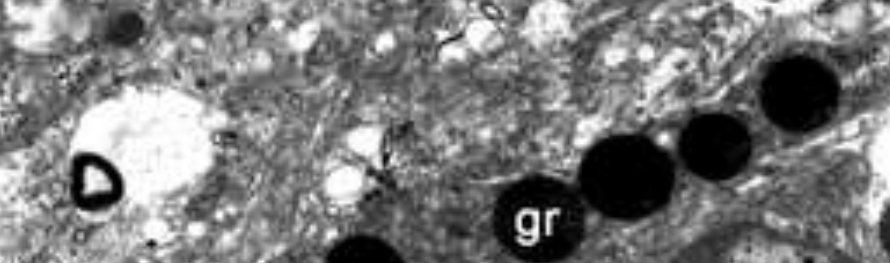

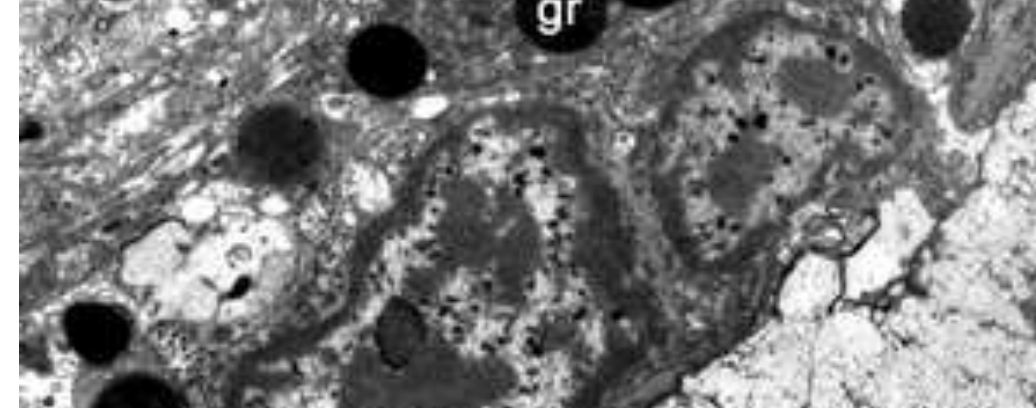

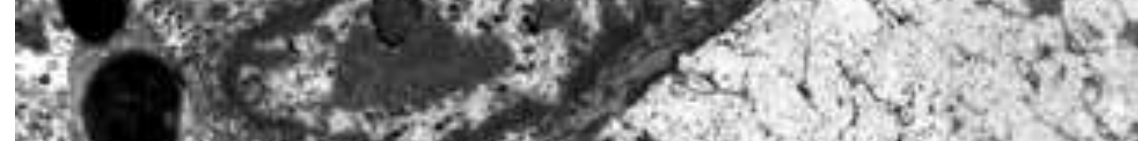

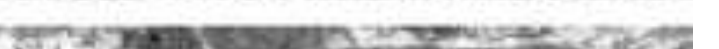

I.

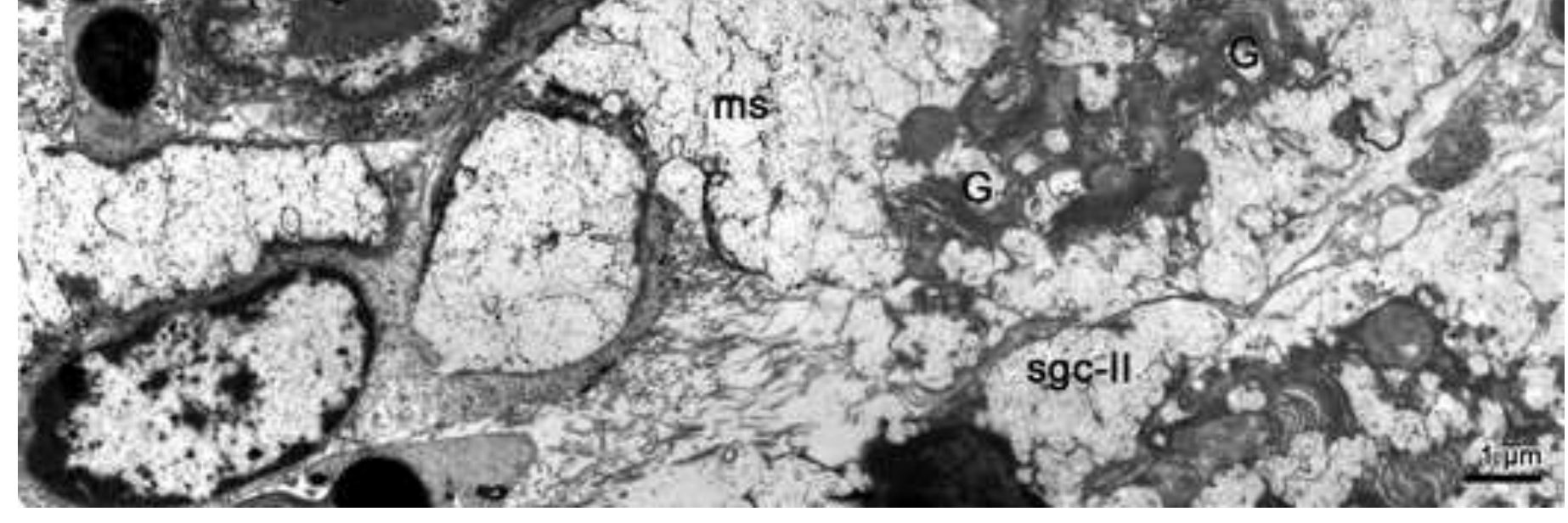



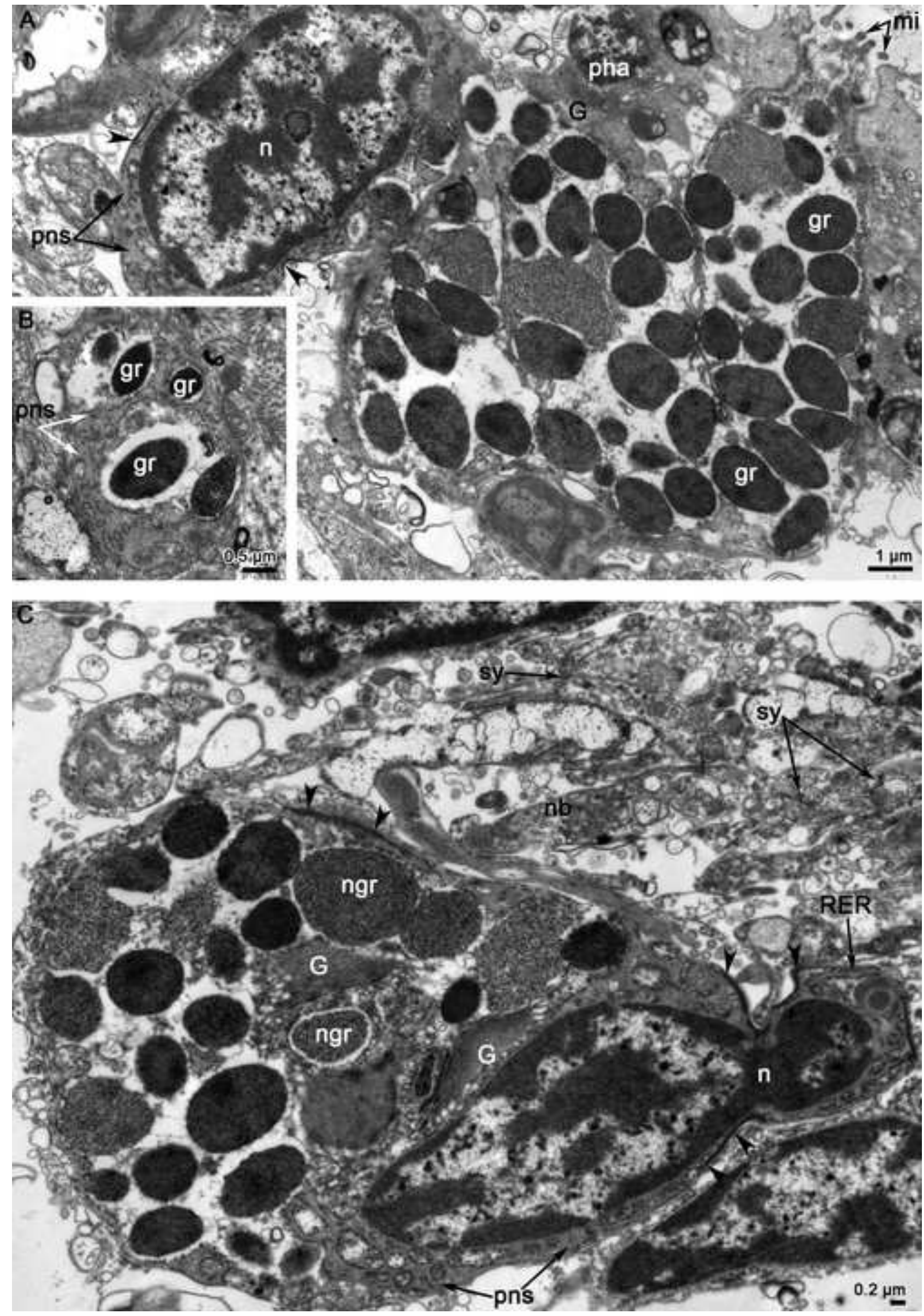